بررسى فرونشست زمين در دشت نجفآباد اصفهان با استفاده از تكنيك تداخلسنجى تفاضلى

\author{
رادارى \\ كورش شيرانى "، مهرداد بـندى ' و بابك ابراهيمى"

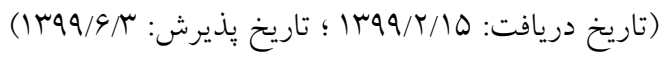

جكيده

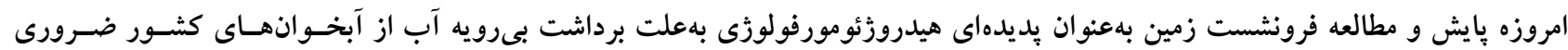

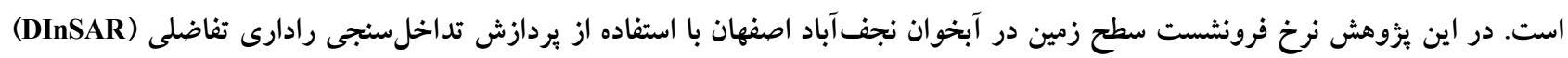

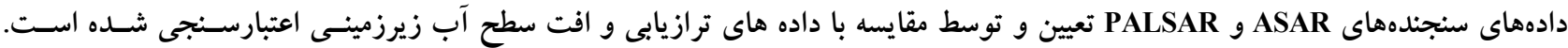

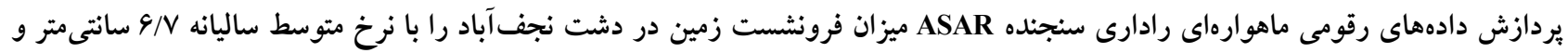

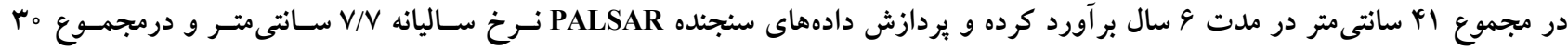

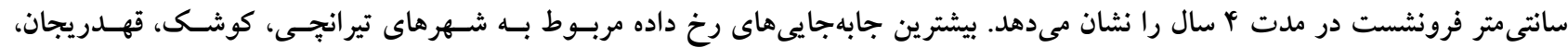

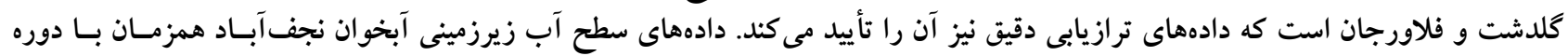

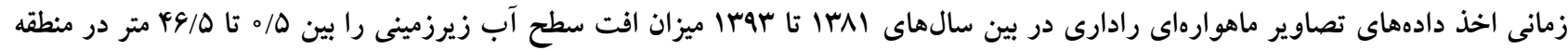

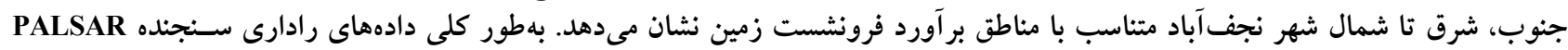

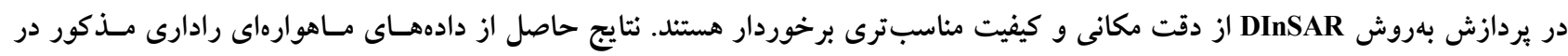

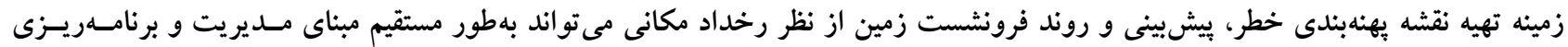

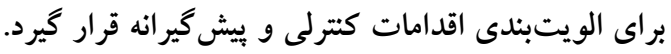

وازههاى كليدى: فرونثست زمين، آبخوان نجفآباد، تداخلسنجى رادارى، ترازيابى، PALSAR ASAR،

ا. بخش تحقيقات حفاظت خاك و آبخيزدارى، مركز تحقيقات و آموزش كشاورزى و منابع طبيعى استان اصفهان، سـازمان تحقيقـات، آمـوزش و ترويج كشاورزى، اصفهان، ايران

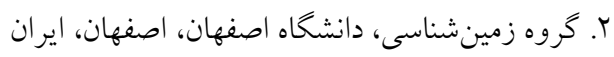

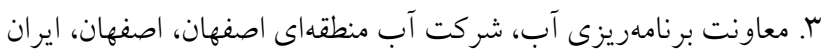

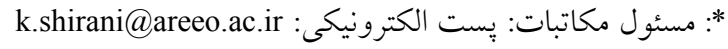


ترازيابى دقيق و استفاده از گمانه، انبساطسنج (Extensometer)،

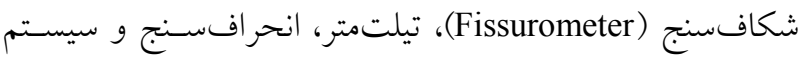
موقعيتيابى جهانى (GPS) است. برداشتهـا در ايـن روشهـا

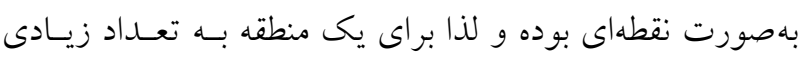
اندازهيرى نياز است (9). (ب) امروزه تــاخلسـنجى رادارى دريجـهـ مصـنوعى InSAR و بلهويزه تداخل سنجى رادارى تفاضلى (D-InSAR) بهعنوان يـك

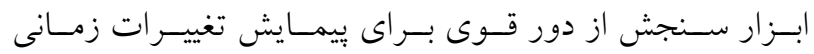
جابهجايى قائم سطحى اسـتفاده مسى شـود. يوشـش سراسـرى و

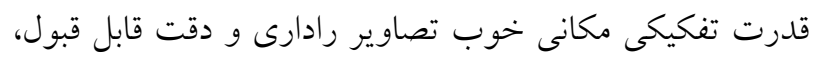
اين روش را بهعنوان ابزار نيرومندى براى مطالعه و اندازهيــرى

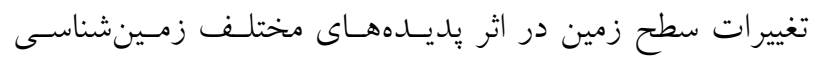

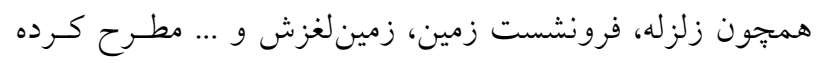

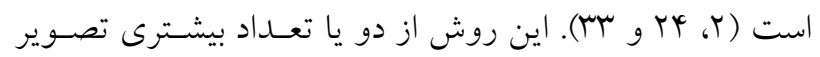

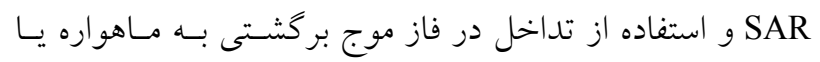

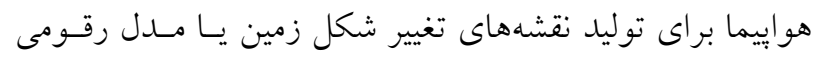

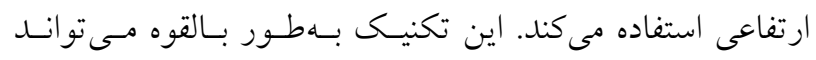

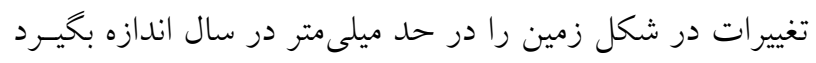

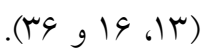

بيش از 010 شهر در جهان وجود دارنــ كـهـ بـا مشكلات

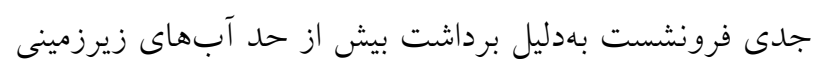

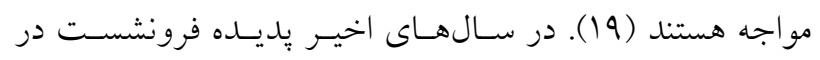

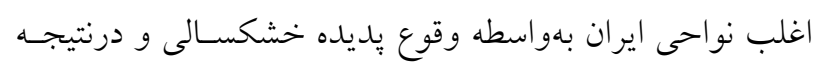

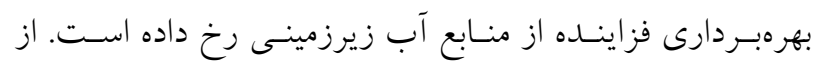

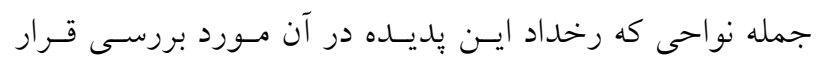

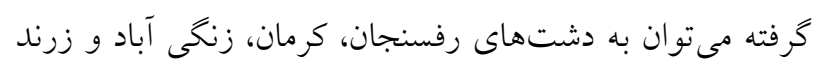

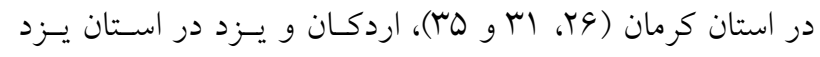

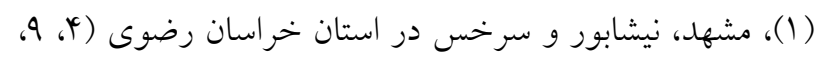

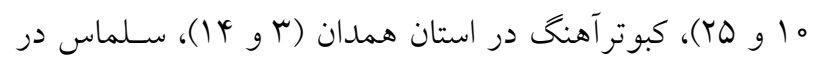

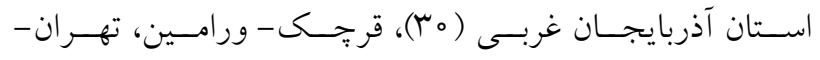

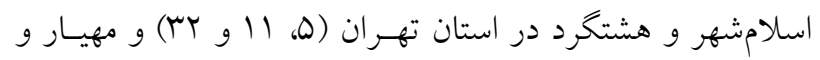
دامنه در استان اصفهان (1 و 1) اشاره كرد.

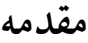

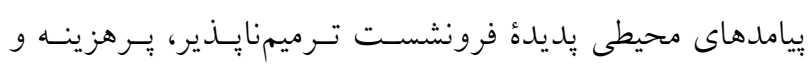

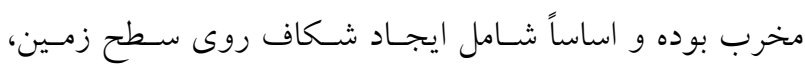

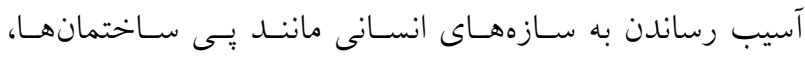

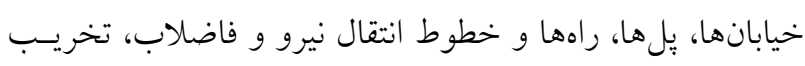

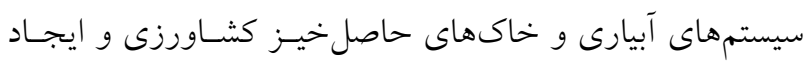

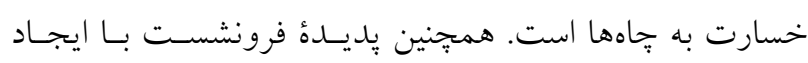

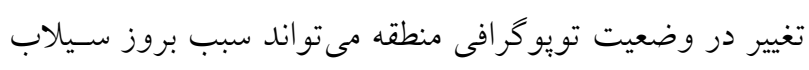

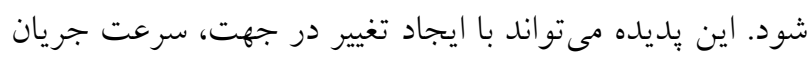

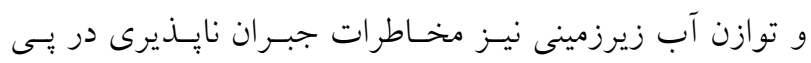
داشته باشد.

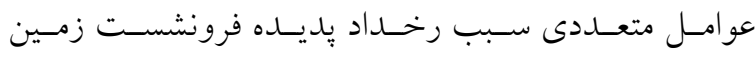

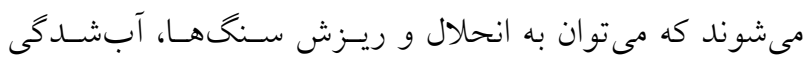

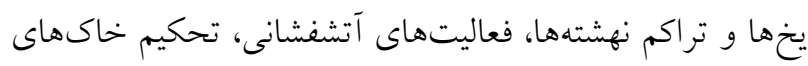

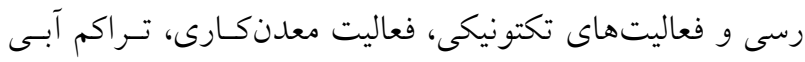

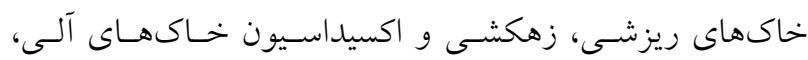

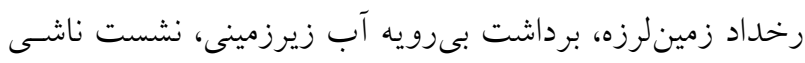

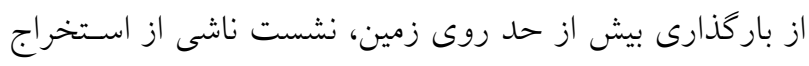

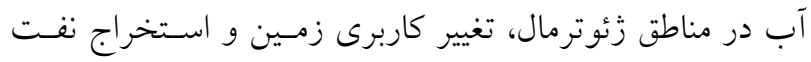

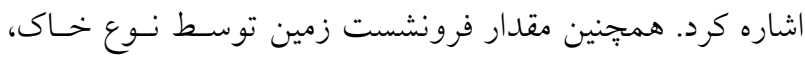

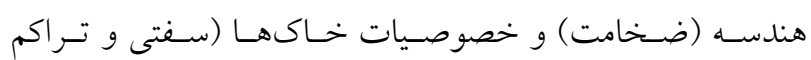
يذيرى) و تاريخجه بار كذارى كنترل مى هود. بهدليل تغيير اقلـيم

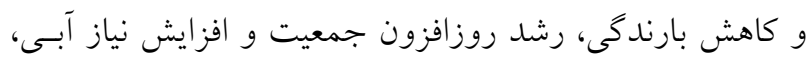

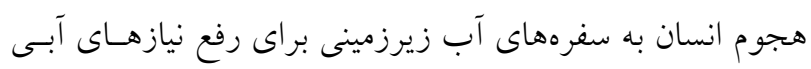

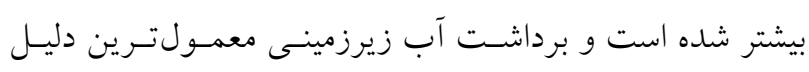

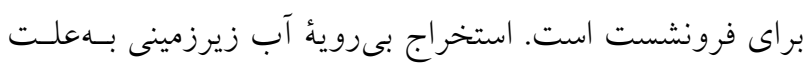

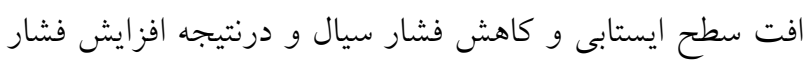

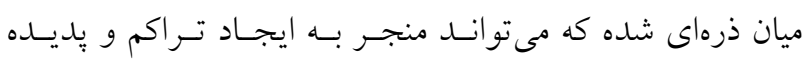

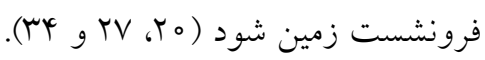

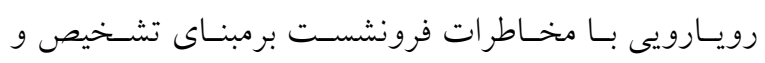

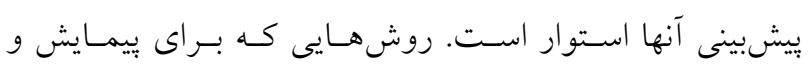

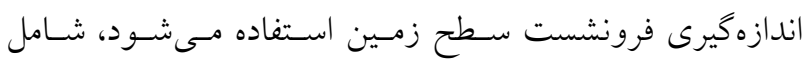




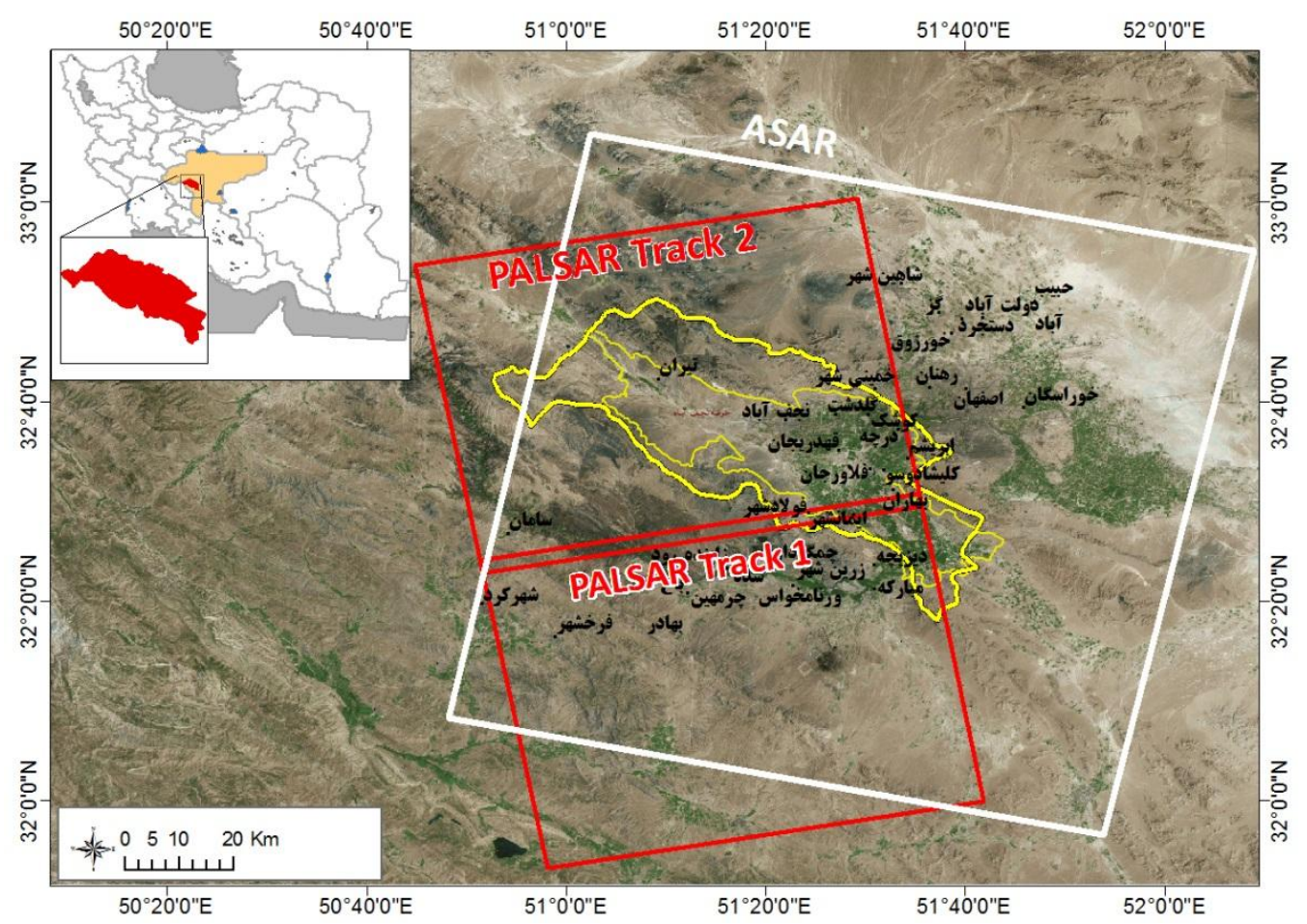

شكل 1. موقعيت جغرافيايى و كذرهاى تصاوير رادارى ASAR، PALSAR استفاده شده در محدوده مطالعاتى نجفآباد

ASAR دادههاى مـاهوارهاى رادارى سـنجندهـLاى (DInSAR)

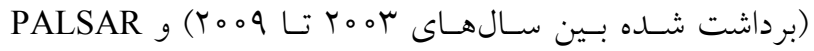

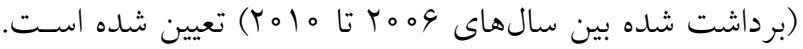
با بررسى و مقايسه دادههاى ترازيابى بين سالهـاى سكو تـا سمی و

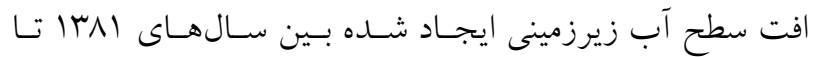
rاهו، تعيين ميزان و گستره فرونشست زمين مورد اعتبارسنجى و ارزيابى قرار گرفته و دقـت تصـاوير ASAR و PALSAR در شناسايى فرونشست زمين ارزيابى شده است.

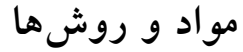

موقعيت منطقه مورد مطالعه

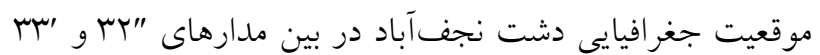

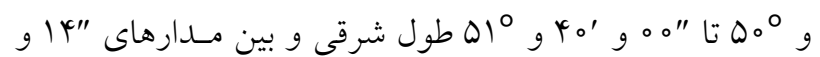

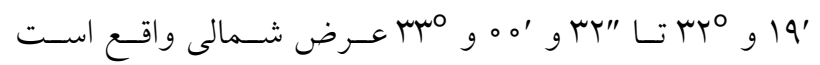
(شكل (). محدودهه مطالعاتى نجـف آبـاد از شـمال بـه محهـدوده

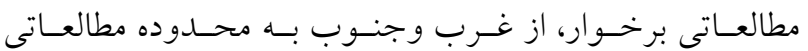
لنجانات و از شرق به محدوده مطالعاتى مهيار شمالى و كوهيايه

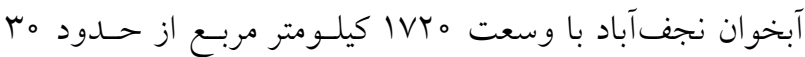

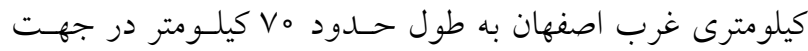
غرب و شمال غرب امتداد مىيابـــ. ايسن حوضـهـ از شـمال بـهـ حوضههاى اصفهـان-برخـوار و علويجـهـ-دهـق، از شـرق بـهـ حوضه كوهيايه-سخزى، از غرب به حوضه كرون و جادكـان و از جنوب به حوضه لنجانات و مهيار شمالى محدود شده اسـت. رودخانه زايندهرود از ناحيه جنوب شرق دشت نجفآباد عبـور مى كند. اين منطقه بهدليل موقعيت خاص از لحاظ كشاورزى در

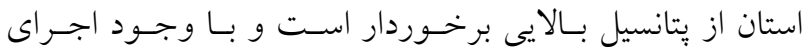

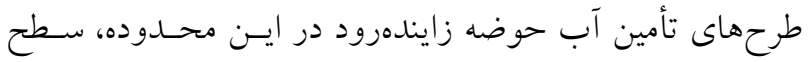

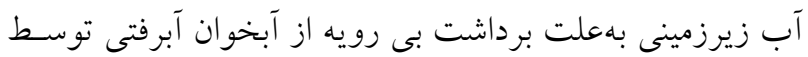

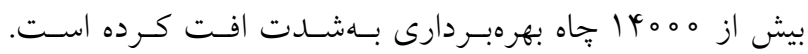

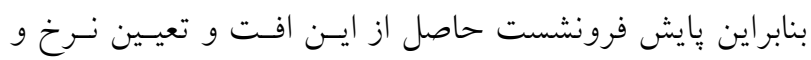

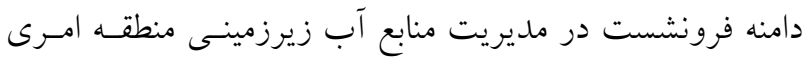
كاملاً ضرورى است. فروسئ.

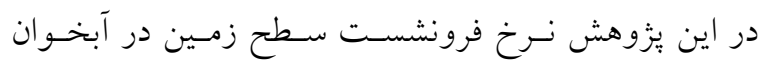

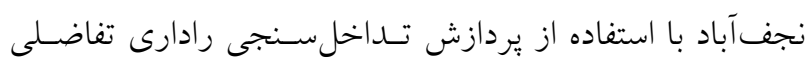


شمال به حوضههاى اصـفهان- برخـوار و علويجـه-دهـق، از

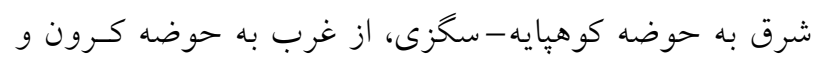

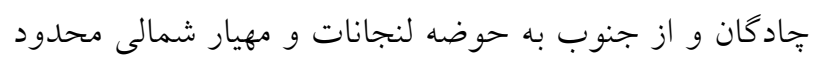

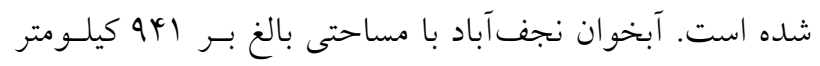

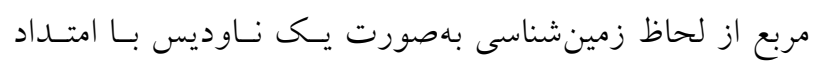

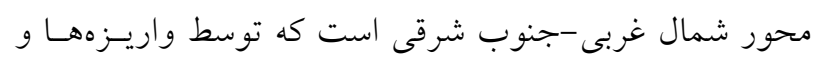

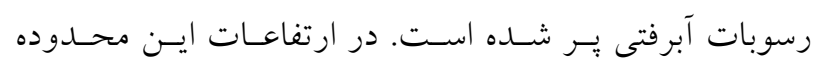

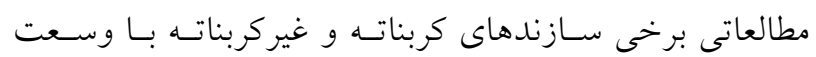
ت كيلو VTY/D تشكيل دادهاند كه نقش اندكى در تغذيه آبخوان آبرفتى دشت آنست

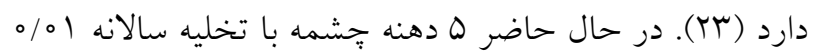

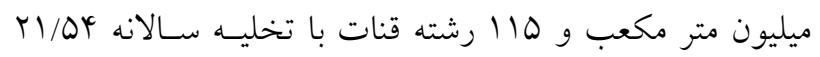

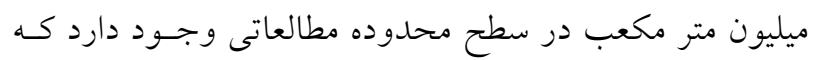

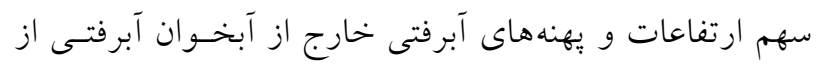

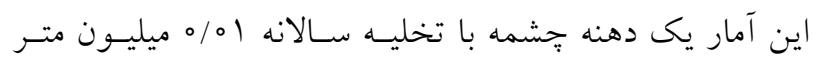

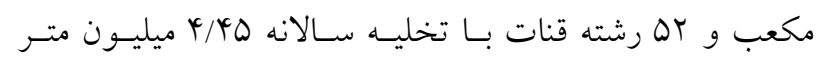

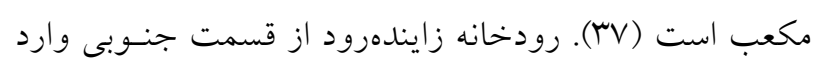

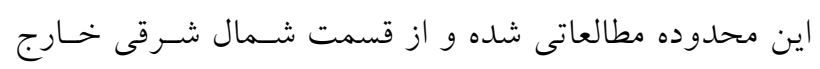

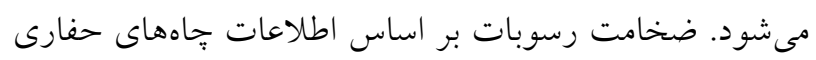

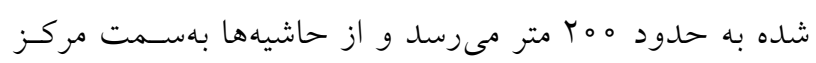

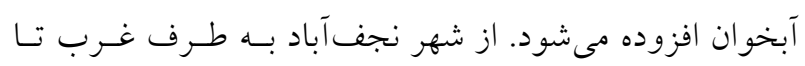

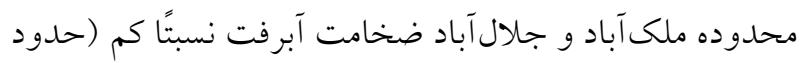

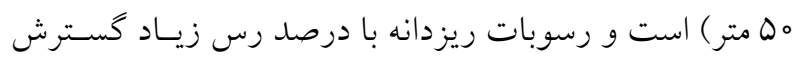

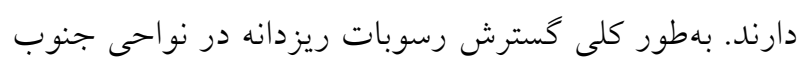

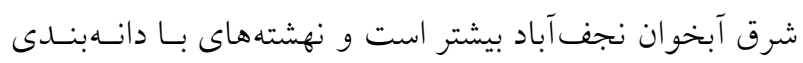
درشت در ساير نواحى بيشتر گسترش دارند. سنخ كف آبخوان

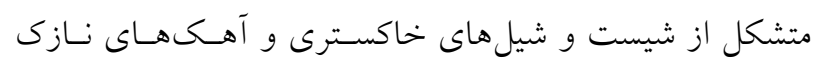

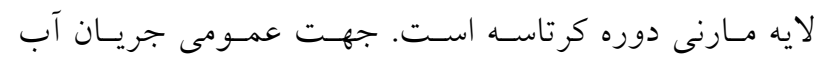

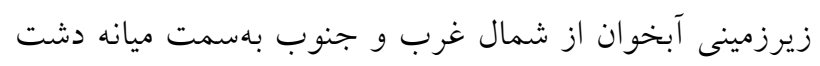

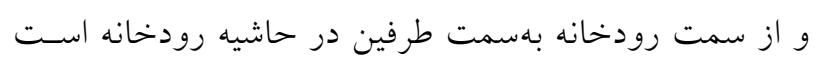

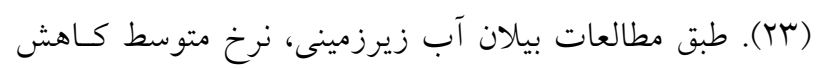

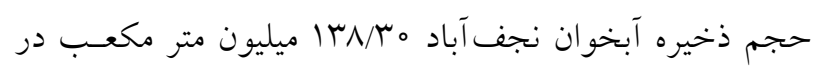

سكَى محدود مىشود. مهمترين مناطق مسكونى واقـع در ايسن

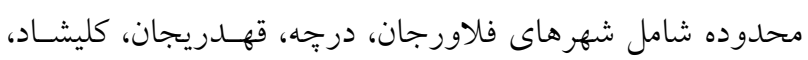

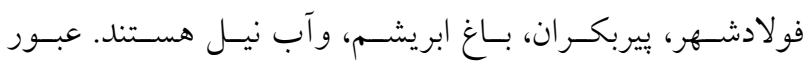

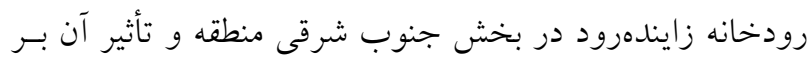

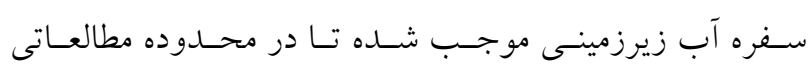

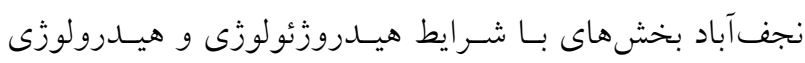

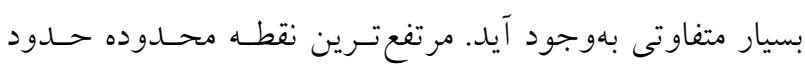

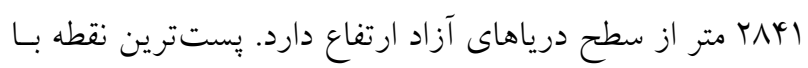

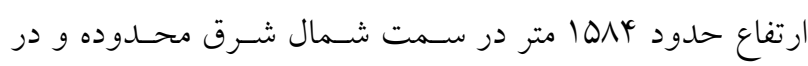
محل خروج رودخانه زايندهرود از محدوده مـورد مطالعـه قـرار كرفته است.

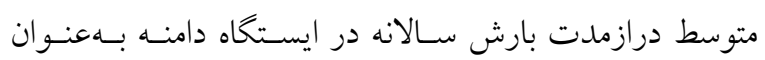

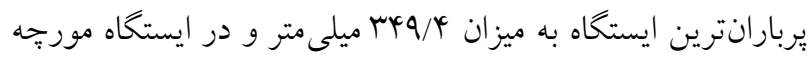

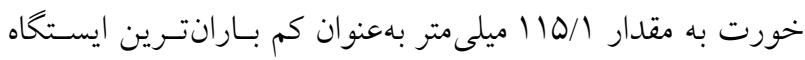

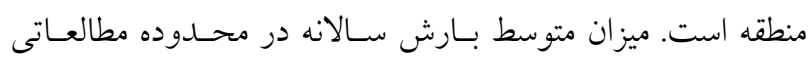

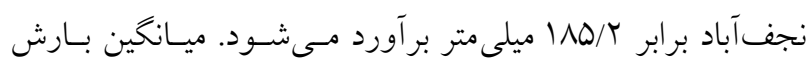

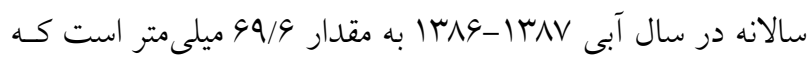

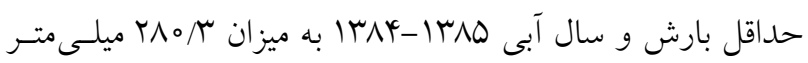

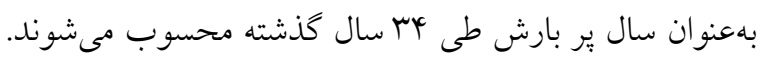

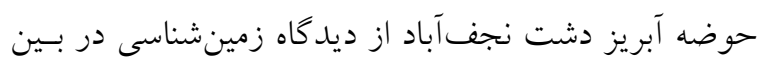
ارتفاعات يهنه تكتونيكى سنندج - سيرجان محصور شده اسـت دئ.

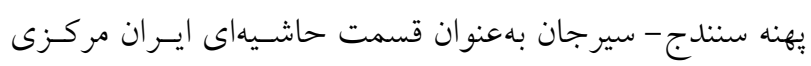

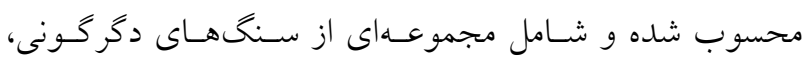

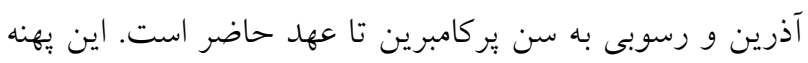

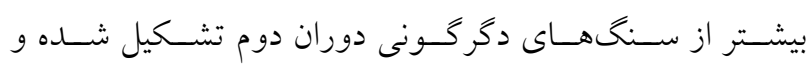
سنگهاى دوران سوم گسترش خيلى كمى در اين بهنه دارد.

\section{هيدروزئولوزى دشت نجفآباد}

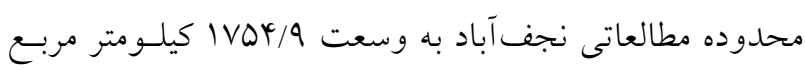

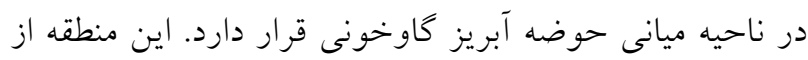

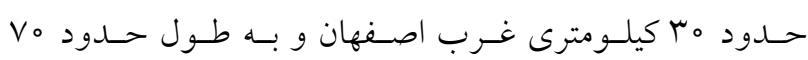

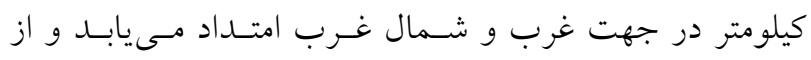


است. همجنْنين تعداد و جزئيات دادههـاى مـورد اسـتفاده در

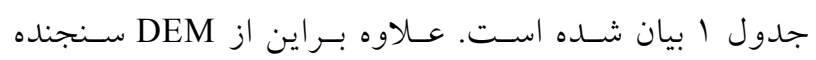

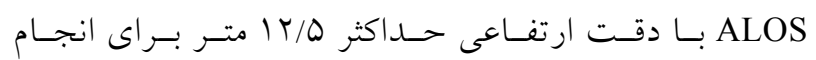

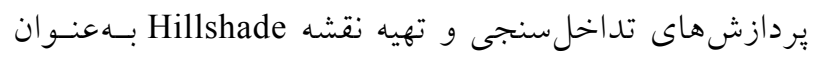

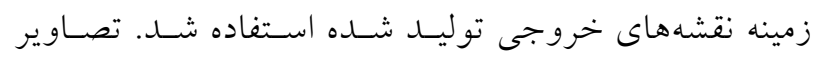
سنجش از دور ايتيكى سنجنده

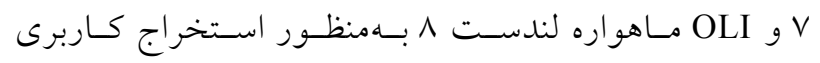

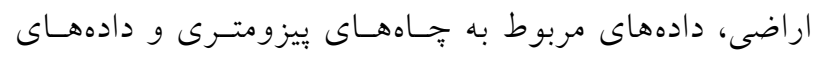

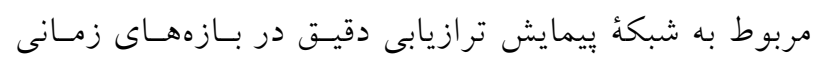

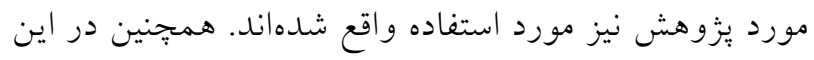

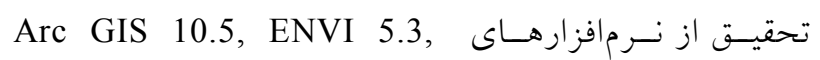
SARscape 5.2

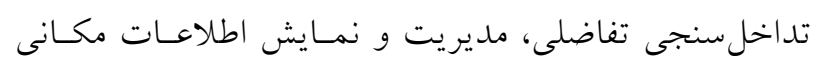

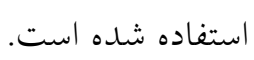

\section{روش تحقيت}

مراحل روش تحقيق در دو بخش اصلى انجام شده اسـت. ابتـدا

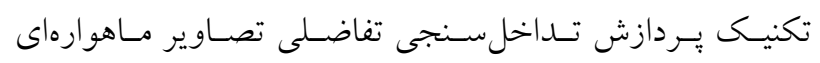

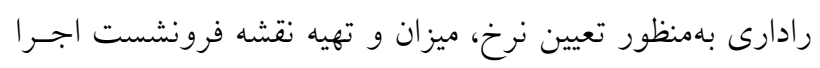

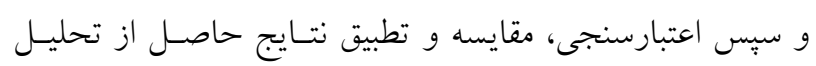

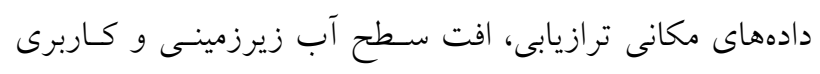
اراضى دشت صورت گرفته است.

تداخلسنجى تفاضلى رادارى با دهانه تركيبى (DInSAR)

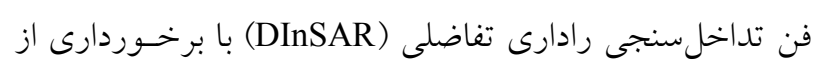

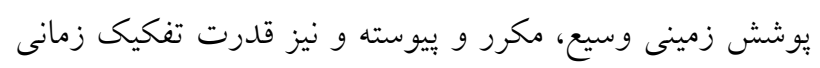

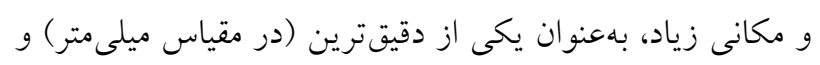

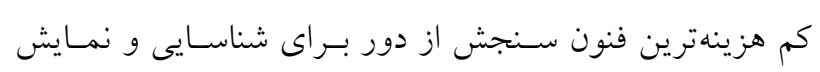

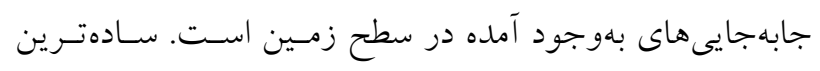

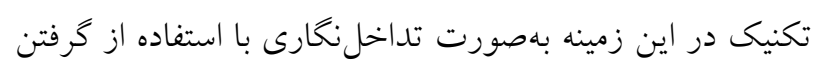

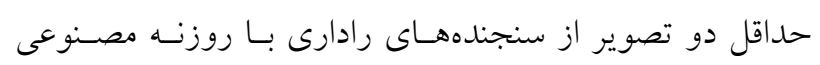

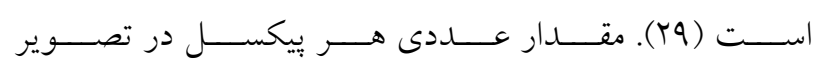

سـال اسـت و رودخانـه زاينـدهرود در مسـير كـــر از دشـت نجف آباد بهدليل افت شديد سطح آب زيرزمينى، تغذيه كنـــهـ

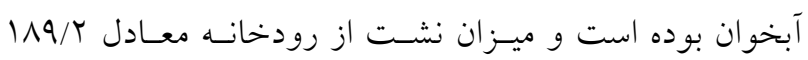

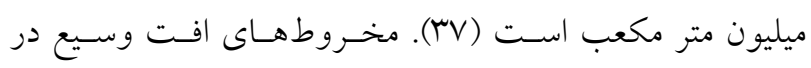

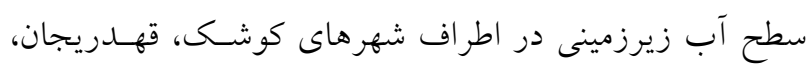

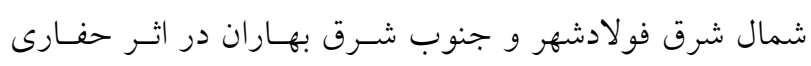
جاههاى عميق و برداشت بى رويه آب زيرزمينى ايجاد شده و و

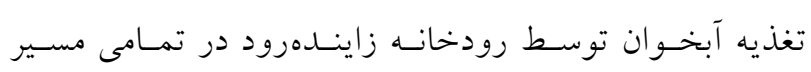

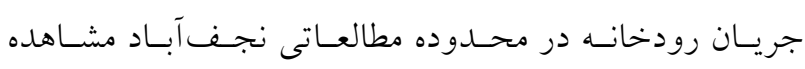

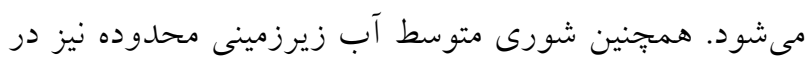

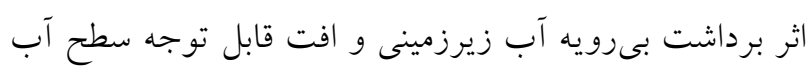

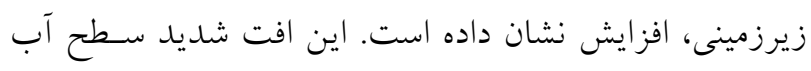

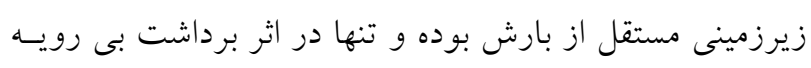

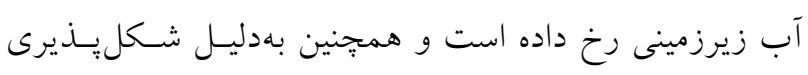

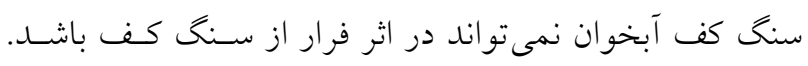

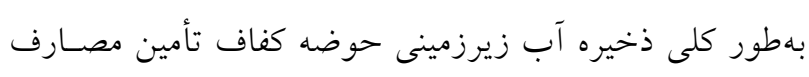

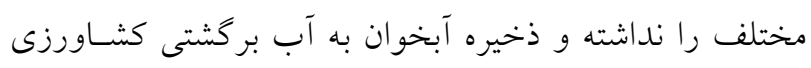

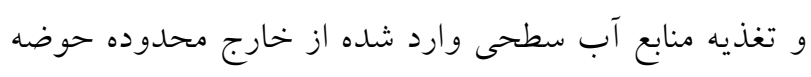

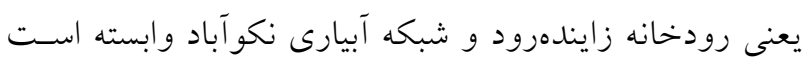

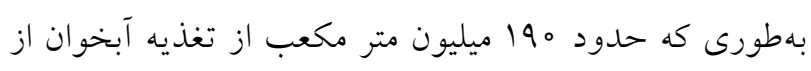

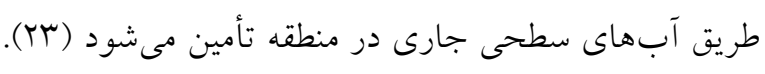

دادهها و نرمافزارهاى مورد استفاده

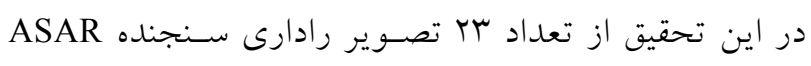

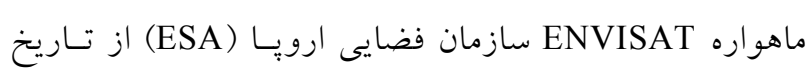

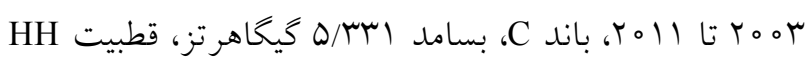

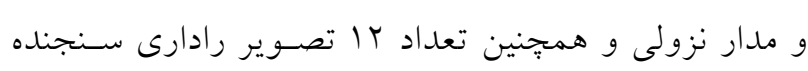

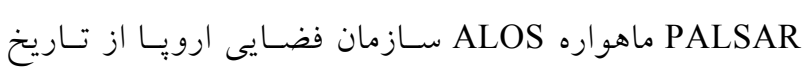

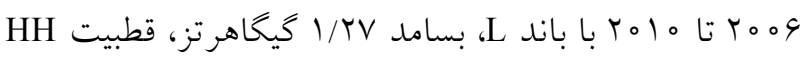

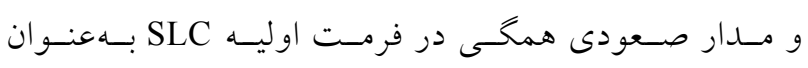

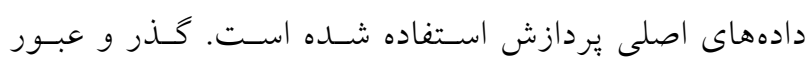

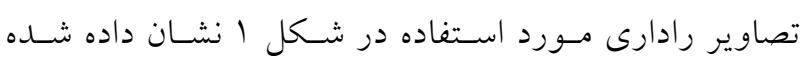


جدول ا. اطلاعات دادههاى SAR مورد استفاده

\begin{tabular}{|c|c|c|}
\hline ALOS PALSAR & ENVISAT ASAR & سنجنده \\
\hline $\mathrm{L}$ & $\mathrm{C}$ & باند \\
\hline$r M / 9$ & $0 / 9$ & طول موج (سانتىمتر) \\
\hline$-10 / T V Y \circ Y \circ O$ & $-11 / 94 r 9000$ & سمت (درجهة) \\
\hline MN/VTHG & TY/V991 & زاويه فرود (درجه) \\
\hline $\mathrm{HH}$ & VV & قطبش \\
\hline 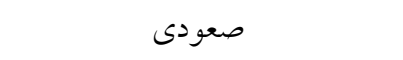 & 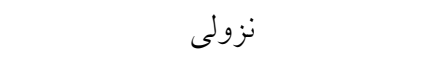 & حركت مدارى \\
\hline 10 & r。 & دقت مكانى (متر) \\
\hline ir & r & تعداد تصوير \\
\hline 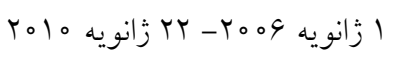 & 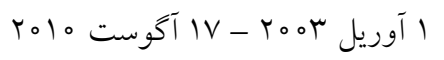 & دوره زمانى دادهها \\
\hline
\end{tabular}

تركيبـى (DInSAR) روى تصـاوير سـنجندههـاى ASAR و PALSAR بهمنظور تعيين نرخ و ميـزان فرونشسـت زمسين در دشت نجف آباد اصفهان در قالب و مرحلـه ذيـل انجـام شـده

\section{انتخاب زوج تصاوير}

ييش يردازش رادارى مربوط به هر سنجنده از لحاظ خط مبنـاى مكانى و زمانى بهصـورت مسـتقل بـهـصـورت دو بـهـ دو انجـام كرفت و انتخاب زوج مناسب تصوير مطابق با خط مبناى مكانى

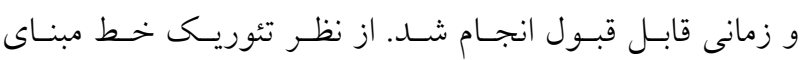

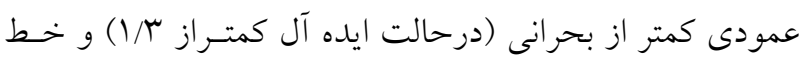
مبناى زمانى كمتـر از يـك سـال بايسـتى درنظـر كرفتـه شـود. بنابراين انتخاب تصاوير SAR مناسب براى ايجــاد تــداخلنخـــار بر اين اساس انجام شده است. اين يـك مرحلـه كليـدى اسـت، زيرا معيارهايى كه براى انتخاب تصاوير اتخــاذ مسىشـود، تـأثير زيادى بر كيفيت نتايج بايانى دارد. همجنين معيارهـاى انتخـاب تصاوير SAR مناسب، تابع زاويه ديد (عبور بالارونــده و يـايين رونده)، زمان كسب دادهها، همدوستى و شرايط هواشناسسى نيـز

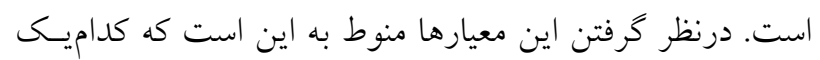
از كاربردهاى ويزه تصاوير SAR مورد نياز است (ه (1). معمـولاً

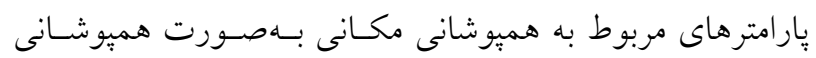

SLC (Single Look Complex) و فاز تشكيل يافته است. اين فاز بهصورت مطلق معلـوم نيسـت

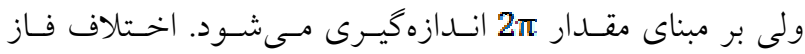

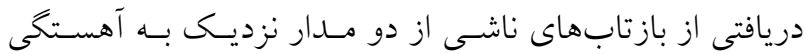
تغيير مى كنند. اين اختلاف فاز محاسبه شده بــراى هـر بيكسـل، همان تداخلنگار است. بهعبارت ديخر مقدار تغييرات مربوط به فاصله عارضه تا سنجنده رادارى در تداخلنگار موجـود اسـت. اين تغييرات مربوط بـه خطـاى مــدارى مـاهواره ( توبوگرافى ( عارضــه (

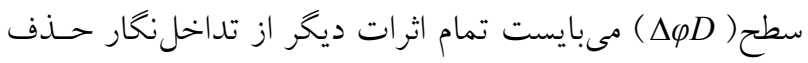

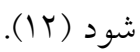

$\varphi_{2}-\varphi_{1}=\Delta \varphi G+\Delta \varphi T+\Delta \varphi A t m+\Delta \varphi D+\Delta \varphi$ noise

سادهترين روش بهمنظور مقابله با مؤلفه تويوگر افى اسـتفاده از تصاويرى است كه داراى حداقل خط مبناى عمـودى اسـت و به اين ترتيب، قسمت اعظم تأثير توبو گرافى در ايجاد اختلاف فاز از بين مىرود. بهمنظور بهبود نتايج مىتـوان از يــ مــل ارتفاعى رقومى زمين استفاده كرد تا بدين ترتيب باقىمانده اثر تويو گرافى را نيز از تصاوير تداخل نخــار ايجــاد شــه، حــف كرد. در اين يزٔوهش تــداخل ســنجى تفاضـلى رادار بــا دهانـه 
ايجاد تصوير همدوسى و اعمال فيلتر

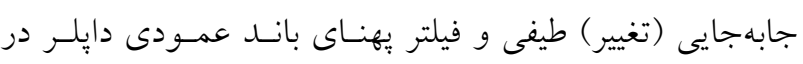
طول فرايند توليد تداخلنخار انجام مىشود. تغيير طيفى با توجه به دامنه تغيير طيفى ناشى از متغير زاويه ديد SAR روى اهداف

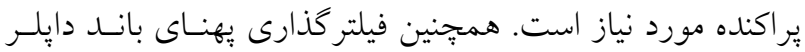

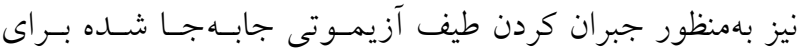

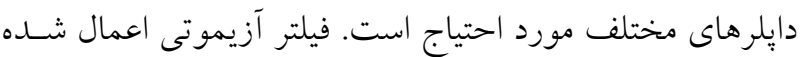
در طول فرايند توليد تداخلنغار قادر به ضبط كامل صحنههـاى با همدوسى بالقوه است. فيلتر كردن تداخل نخـار مسطعح توليسـا شده در مرحله قبل باعث مىشود تا يكى خروجى بـا فـاز نـويز

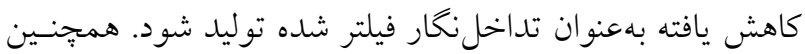
در اين مرحله نقشه همدوسى تــاخلســنهى كـه نشـاندهنـــه كيفيت فاز است و تصوير پايه فيلتر شده نيز توليد مىشـوند. در

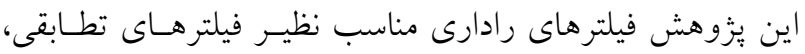

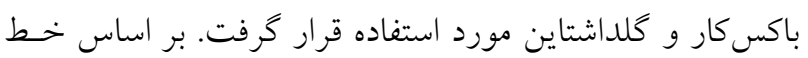

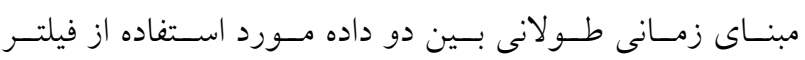

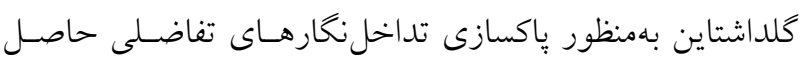
استفاده شده است. بر اساس اين روش متغير بهنـاى بانـــ فيلتـر

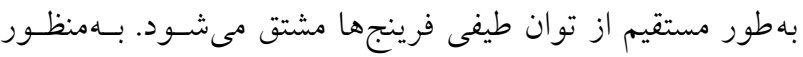

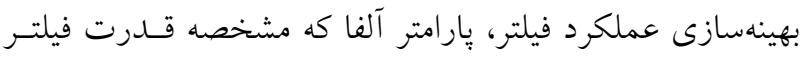
است در يك روش تطبيقى بر اساس همدوسى محلى بهكار برده

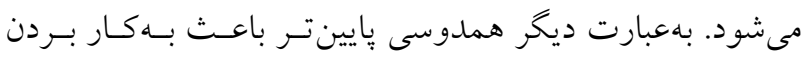

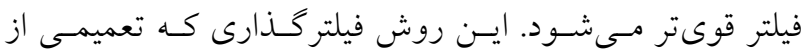
روش كلداشتاين است، بهطور قابل توجهى قابليت ديد فرينجها را بهبود مى بخشد و نويز حاصل از ناهمبستخى مربوط به زمـان و خط مبنا را كاهش مىدهد. در انجـام ايسن روش يـارامتر آلفـا

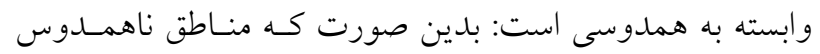

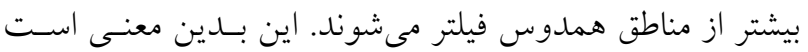

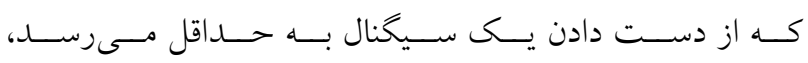

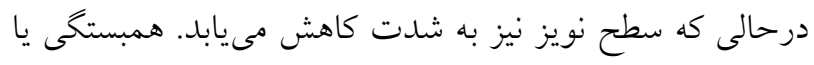

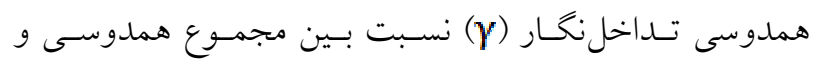

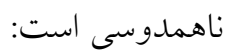

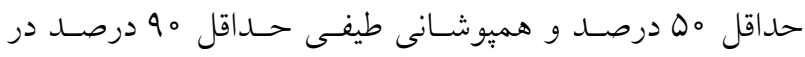

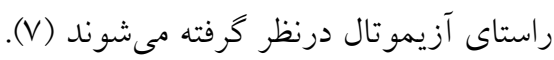

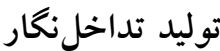

اختلاف فاصله بين يك نقطه روى زمين و موقعيت سـنجنده در دو موقعيت تصويربردارى مى تواند بـا استفاده از اخـتلاف فــاز ( ) بين دو تصوير مختلط بازيابى شده SAR اندازگيرى شود.

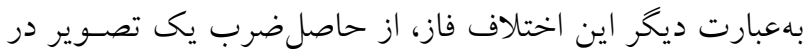

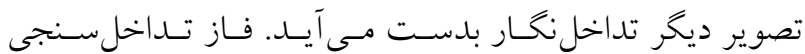
بل اصورت زير بيان مىشود:

Phase $=A \tan [\operatorname{Imag}(I) / \operatorname{Real}(I)]$

در اينجا Real(I) و Imag (I) بهترتيب بخشهاى مجـازى و

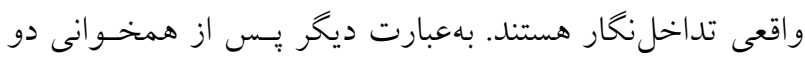

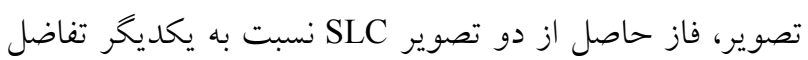

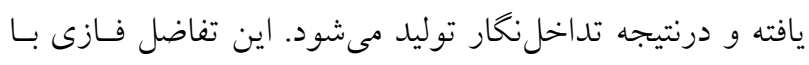

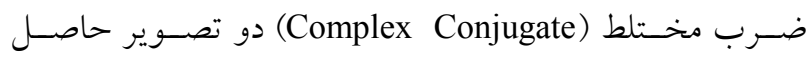

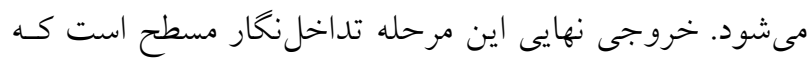

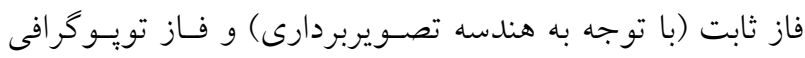

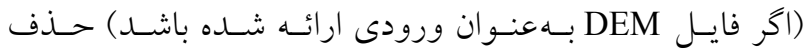
شدهاند. در اين تحقيق جفتهاى تـداخلنخـار تصـاوير رادارى

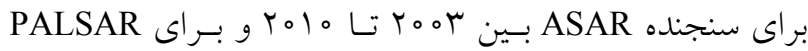

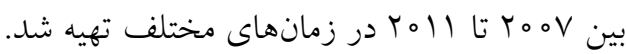

\section{ثبت دو تصوير نسبت به همديخر}

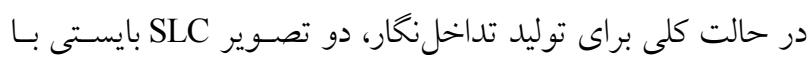

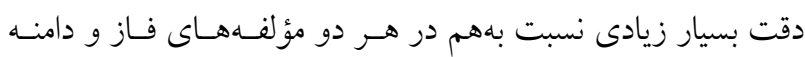

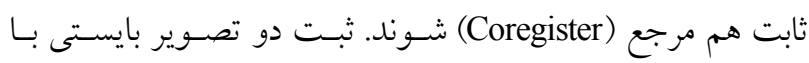

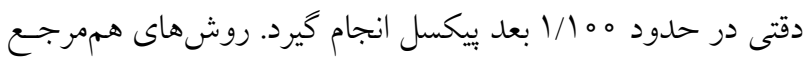
سازى شامل همبستخى تقاطعى(Cross Correlation) مقـادير دامنـه

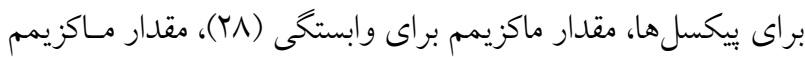

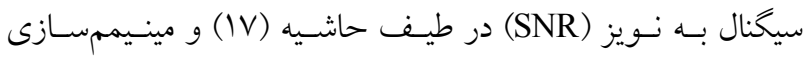
تغييرات ميانخين در تغييرات تفاضلات فازى (YI) هستند. 
يكسرى از الكوريتمهاى خودكار تعيين شود. قابل ذكر است كـهـ

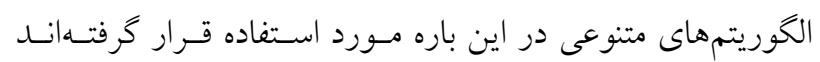

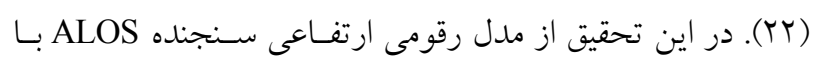

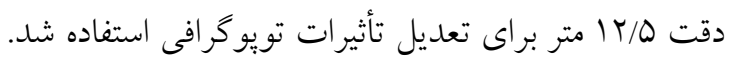

\section{تبديل فاز به جابهجايى و زئو كدينغ}

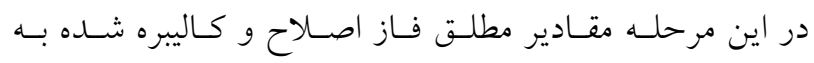

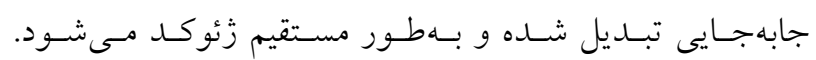

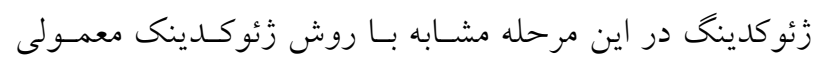

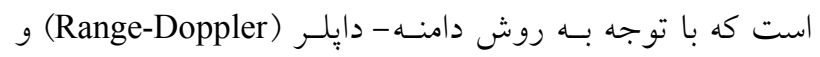

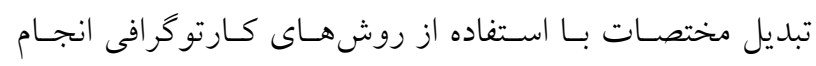

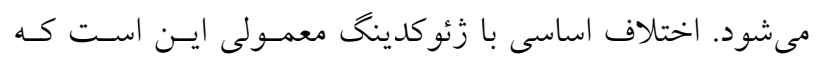
معادلات دامنه- دايلر بهصورت همزمان در هر دو آنستن اعمـال آنسال

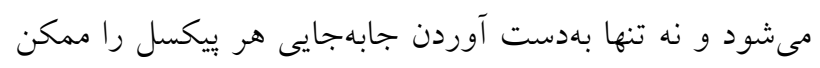

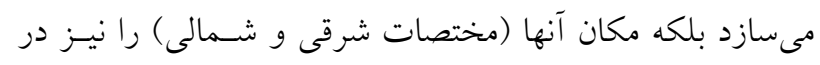

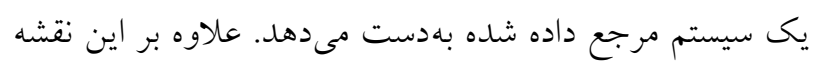

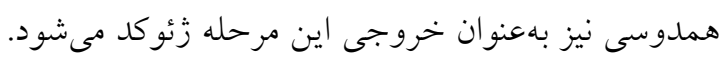

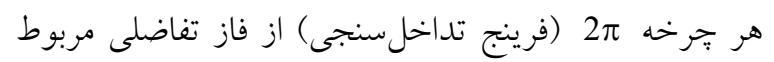

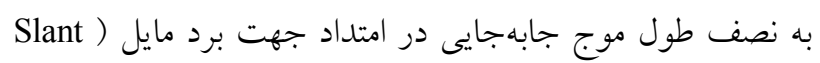
(Range Direction است بهمنظور تعيين هر بردار كه در آن جابهجايى اندازهيرى

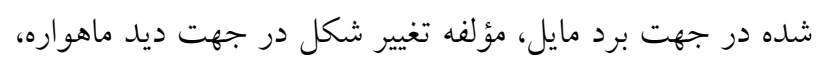

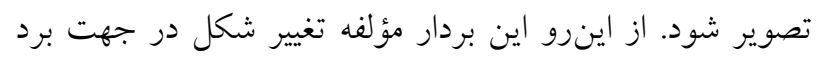

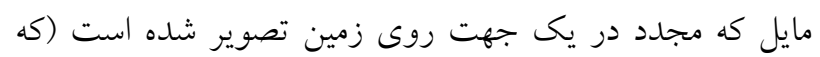

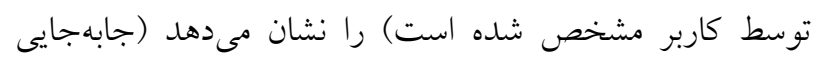

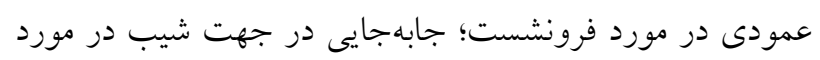

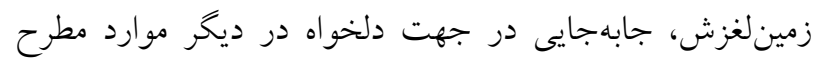

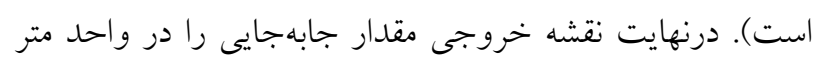

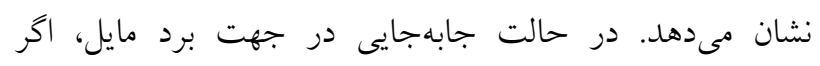

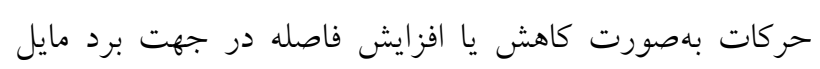

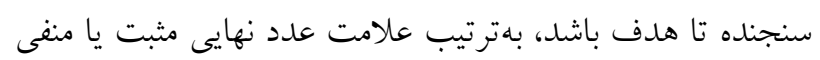

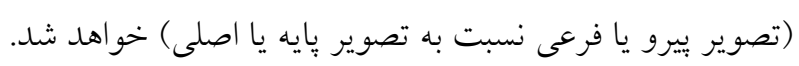

$$
\gamma=\frac{\left|\sum s_{1}(x) \cdot s_{2}(x)^{*}\right|}{\sqrt{\sum\left|s_{1}(x)\right|^{2} \cdot \sum\left|s_{2}(x)\right|^{2}}}
$$

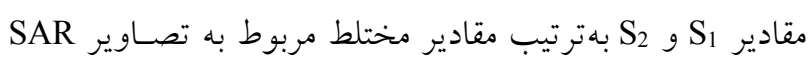

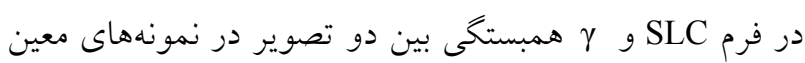

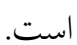
با افزايش ارتفاع عوارض، اختلاف فاز نيز بهتبع آن افـزايش

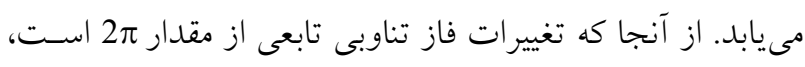

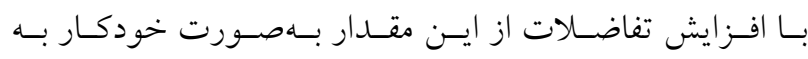

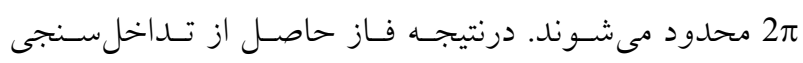

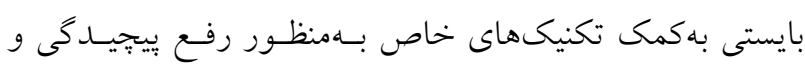

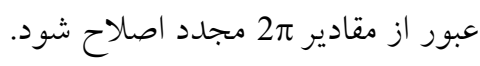

\section{يالايش و تصحيح فاز}

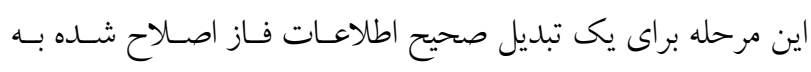

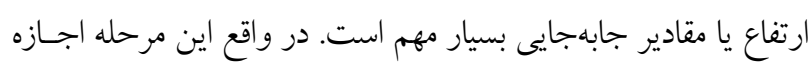

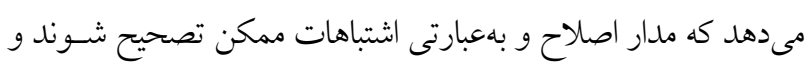

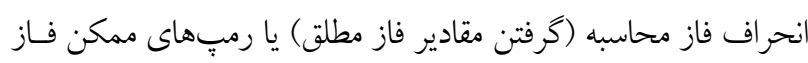

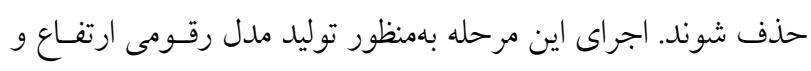

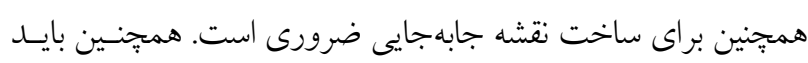

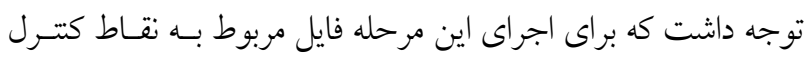
زمينى از قبل بايد ايجاد شود.

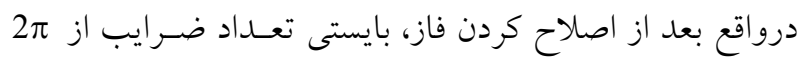

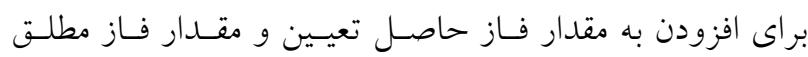

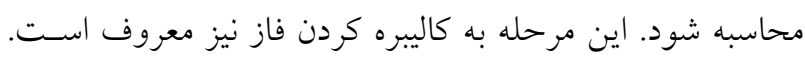
مقدار مطلق فاز در هر نقطه مىتواند بهصورت زير بيان شود: $\varphi_{\text {abc }}=\varphi_{\text {up }}+\varphi_{\text {offset }}$

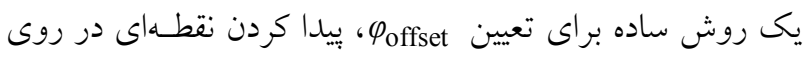

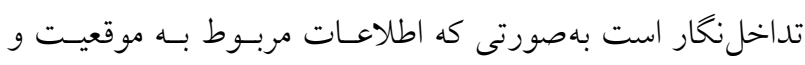

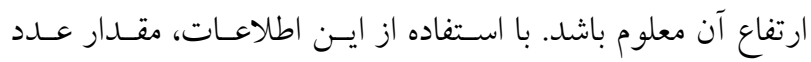

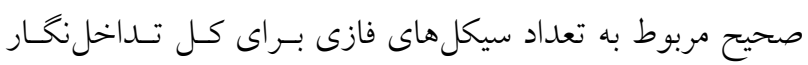

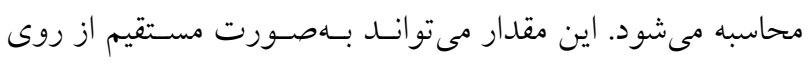

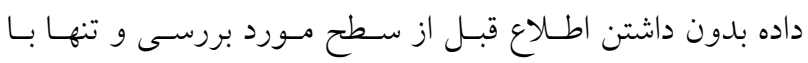




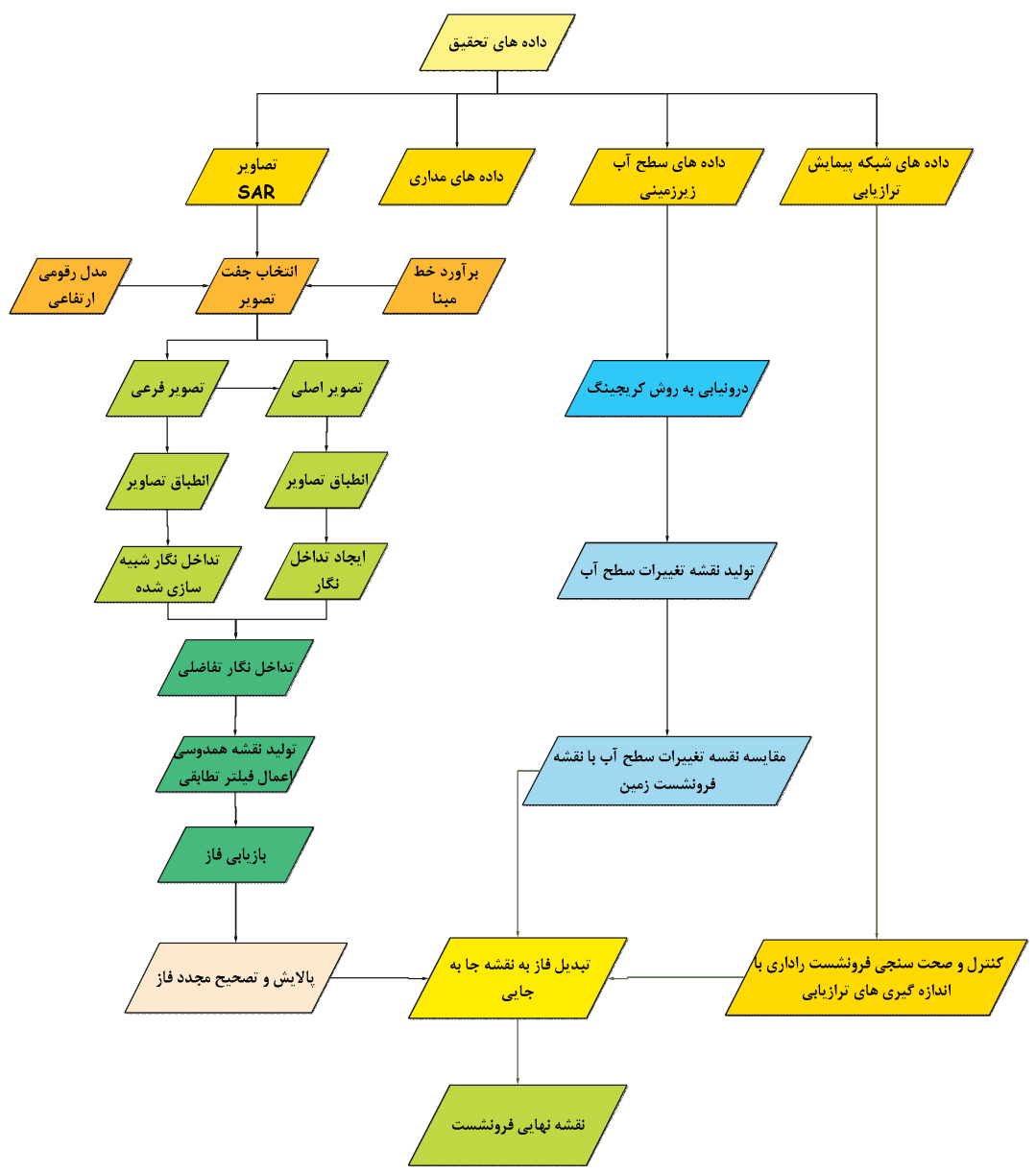

شكل r. نمودار روش تحقيق در قالب يك مدل مفهومى

نقشههاى هم افت سطح زمين (فرونشست) در بازههـاى زمانى

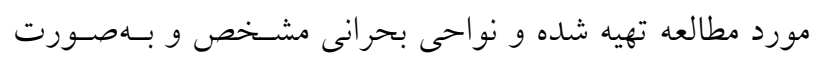

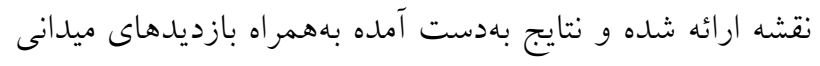
كتترل و بررسى شد.

اعتبارسنجى و صحتسنجى نقشههاى فرونشست زمين

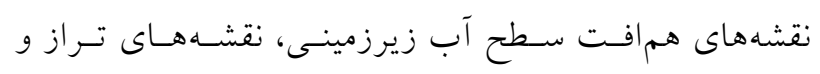

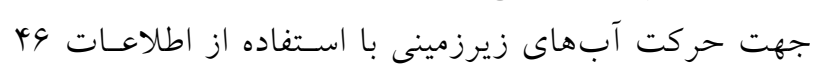

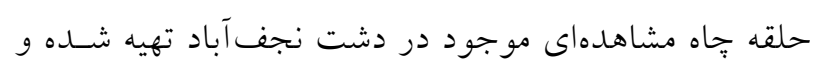

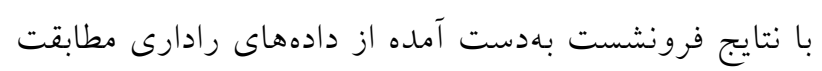

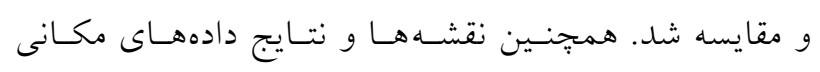

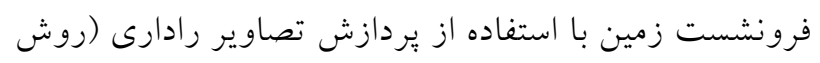

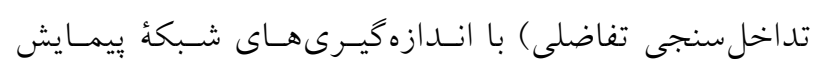

همجنين فايلى با عنوان Precision نيز بهعنوان خروجى در ايسن

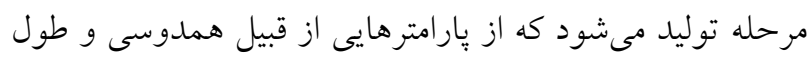

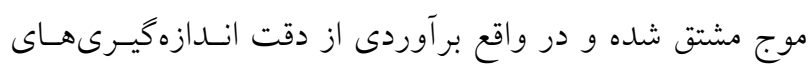

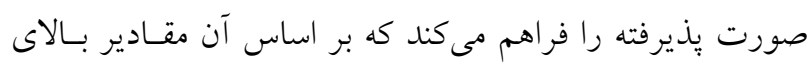

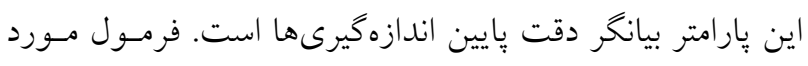

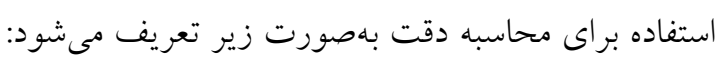

$\sqrt{\frac{1-\gamma^{2}}{2 \gamma^{2}}} \cdot \frac{\lambda}{4 \pi}$

Y بيانكر همدوسى تداخل سنجى است. در نمودار كردشى شكل r كليه مراحل انجام تكنيك تداخل سنجى رادارى تفاضلى آورده

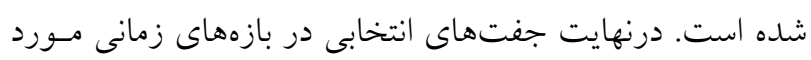

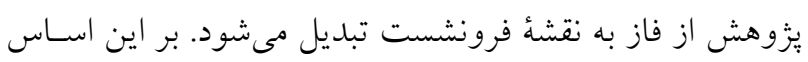


رخ داده مربوط به شهرهاى كوشك، قهــريجان، كلدشـت و

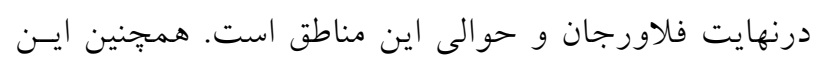

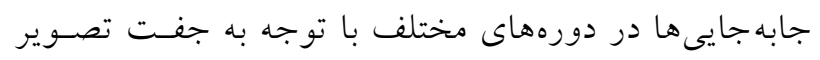
انتخاب شده متفاوت بوده اسـت. از ايسنرو بيشـترين مقــدار

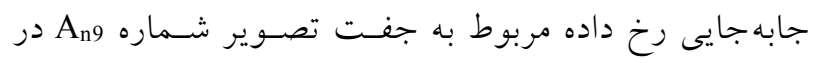

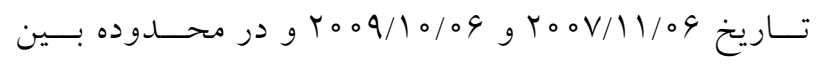

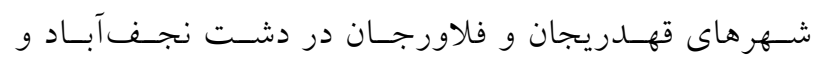

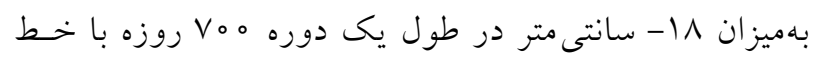
مبناى نرمـال كrV

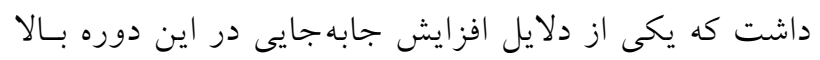

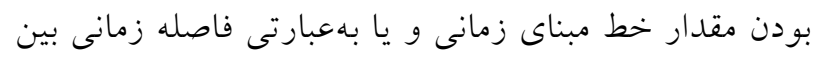
دو تصوير اخذ شده در اين جفت تصـوير اسـت. آنجـه كـه

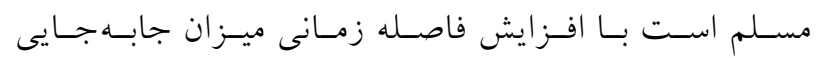

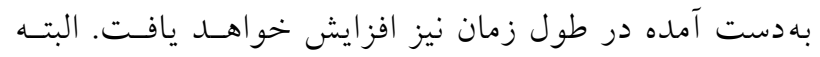
اين افزايش در خط مبناى زمانى موجب كاهش همدوسى نيز خواهد شد. با توجه به جدول Y بيشترين فاصله زمانى بين دو جفت انتخـابى

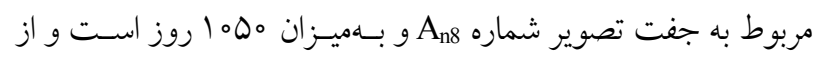

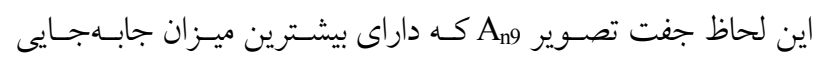

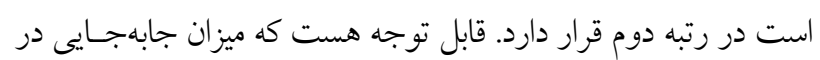

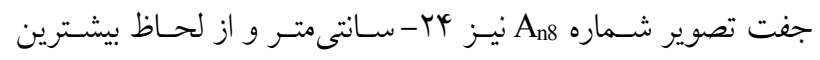

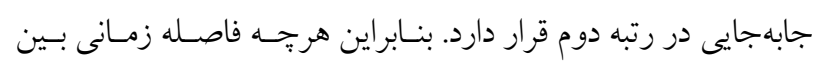

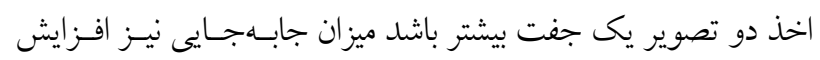

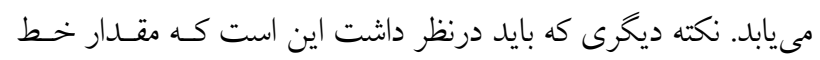

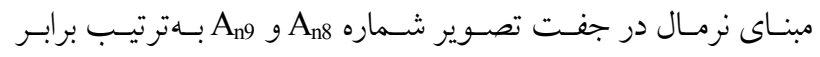

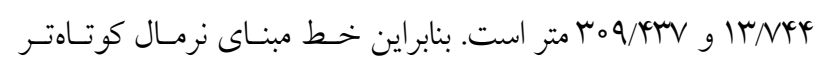
سهم بهسـزايى در بـهدسـت آوردن نتـايج نزديـك بـه واقعيـت دارد.

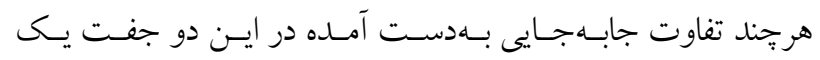

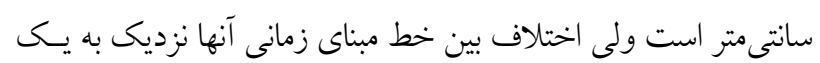

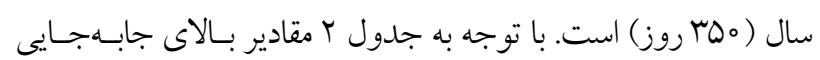

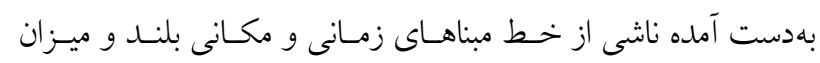

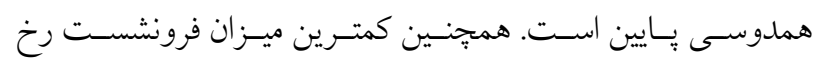

ترازيابى سازمان نقشهبردارى مطابقت، كنترل و صحتسنجى

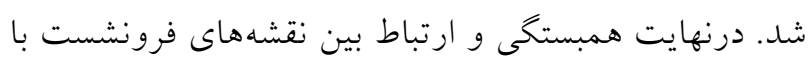

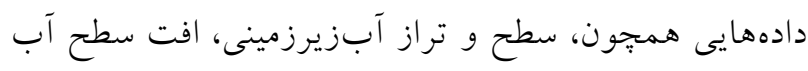

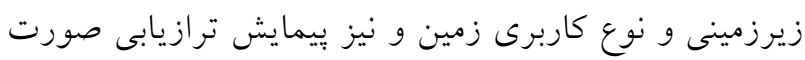

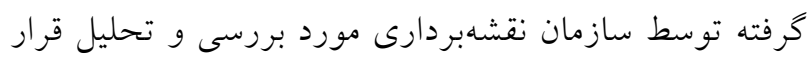
كرفت.

\section{نتايج و بحث} انتخاب زوج تصاوير SAR براى تداخلسنجى

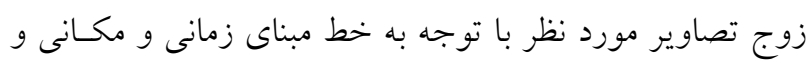

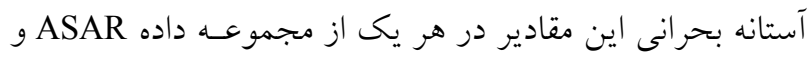

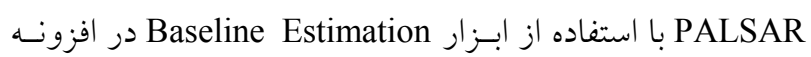

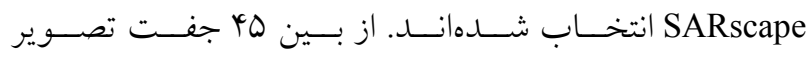
تداخل سنجى ASAR و اب جفـت تصـوير PALSAR تشـكيل شده، 11 و ه ا جفت تصوير بهترتيب مربوط بـه سـنجندههـاى PALSAR و ASAR

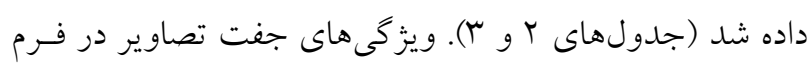

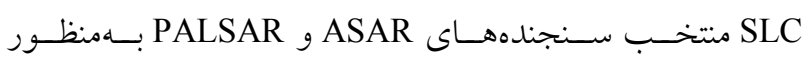

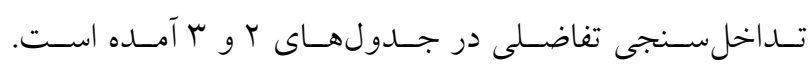

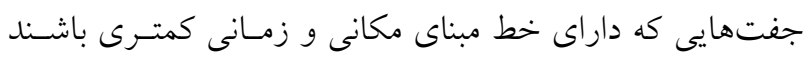

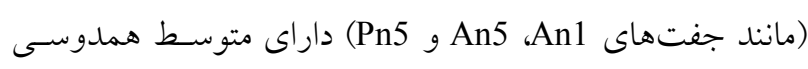

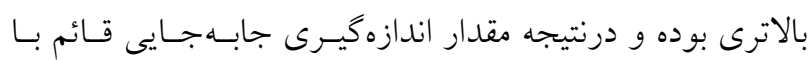

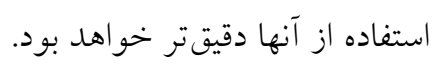
با استفاده از نرمافزار ENVI و افزونه SARscape

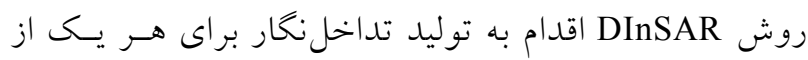

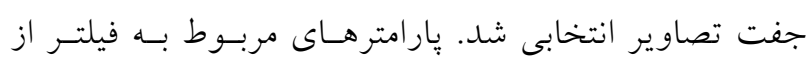

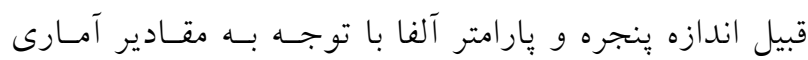

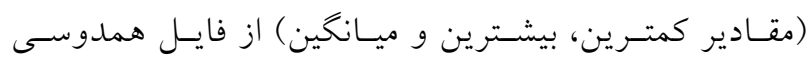

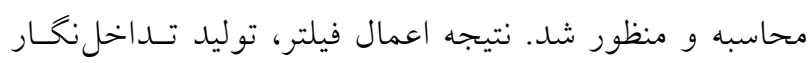
تفاضلى فيلتر شده و هم:جنين تصوير همدوس است. بـا توجه

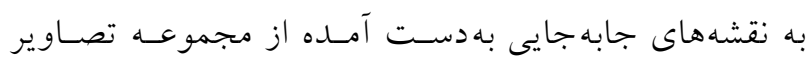

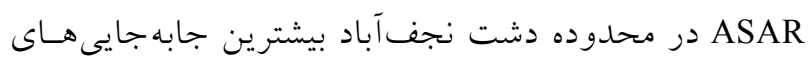


جدول r. زوج تصاوير انتخابى از سنجنده ASAR

\begin{tabular}{ccccccccc}
\hline & & & & & \\
\hline \\
\hline$ر$
\end{tabular}

جدول r. زوج تصاوير انتخابى از سنجنده PALSAR

\begin{tabular}{|c|c|c|c|c|c|c|c|}
\hline فرونشست در محدودهه & مقادير متوسط & زمط مبناى & بحر مبناى & خط مبناى & تاريخ تصوير & تاريخ تصوير & ن \\
\hline-11 & $\circ / \mu \circ V$ & 191 & $1 r \circ 99 / 199 \mathrm{~V}$ & $911 / 9 Y^{4}$ & $r \circ O V / T / / Y$ & $r_{0} \circ 9 / 1 T / 11$ & $\mathrm{P}_{\mathrm{n} 1}$ \\
\hline$-9,0$ & $0 /$ KVT & 94 & $1 r \circ V \circ / 9 Y 4$ & $4 \& 4 / \pi q 1$ & $r \circ \circ N / \circ / / Q$ & $r \circ \circ V / T / / Y$ & $P_{n 2}$ \\
\hline-4 & orNA & 49 & $Q \Lambda \circ Y / \circ \circ 0$ & $V r \Delta / r \wedge q$ & $r_{0} \circ N / 0 \psi^{\prime} / \mu_{0}$ & $r \circ \circ N / \circ r / 10$ & $\mathrm{P}_{\mathrm{n} 3}$ \\
\hline$-\phi$ & $0 / 4 k 9$ & ar & $9 \vee 9 \% / 001$ & $4 V / \% \wedge 1$ & $r \circ \circ N / I T / 19$ & $r \circ \circ N / \circ 9 / 10$ & $\mathrm{P}_{\mathrm{n} 4}$ \\
\hline-9 &.$/ 00 \Lambda$ & ar & $90 \mathrm{rr} / \mathrm{MQq}$ & $105 / 919$ & $r \circ \circ q / \circ q / 11$ & Yooq/09/11 & $\mathrm{P}_{\mathrm{n} 5}$ \\
\hline-0 & okrY & 49 & $9 \vee 91 / 010$ & $F V Y / q I T$ & $r \circ \circ q / 11 / 0 r$ & $r_{0} \circ q / 0 q / 11$ & $\mathrm{P}_{\mathrm{n} 6}$ \\
\hline$-\omega$ & $0 / 401$ & 48 & $\mid r \cdot V G / Q T \Delta$ & $r \Delta r / \Delta Q r$ & $r_{0} 10 / 0 r / r \mid$ & ro10/0r/0r & $P_{n 7}$ \\
\hline-4 &.$/ 40$ & 49 & $Q \Lambda \circ Y / A V I$ & ION/KTO & $r 010 / 0 Q / 0 \varphi$ & $r 010 / 0 r / T 1$ & $P_{n 8}$ \\
\hline-10 & $0 / F a F$ & int & 9OTV/G9T & $\Delta Q Q / \Lambda \& V$ & $r 010 / 11 / 09$ & $r 010 \% 00 / 09$ & $P_{n 9}$ \\
\hline$-r$ & okar & 48 & QVQY/MYO & $901 / 111$ & Y010/IT/TY & $r 010 / 11 / 04$ & $P_{n 10}$ \\
\hline
\end{tabular}

دوره 9 ساله است. همجنين نقشه ساليانه بهدست آمده نيز بيانكر ميزان فرونشست به اندازه 9V- ميلىمتر در سال است.

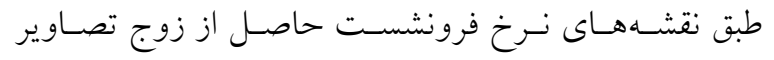
سنجندة PALSAR در مناطق بين شهرهاى كوشك، قهـدريجان،

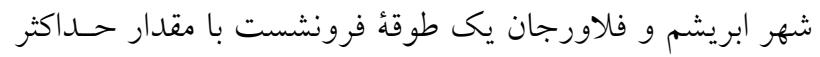

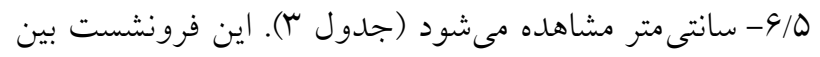

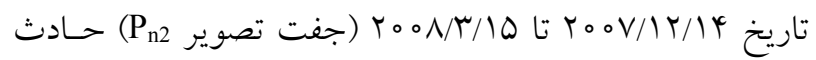

داده مربوط به جفـت تصـاوير An و An و و بـهميـزان مشـترى

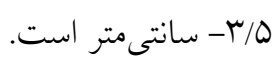

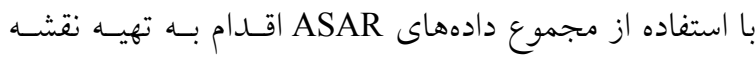
فرونشست كل برحسب سـانتى متـر (شـكل بـ الـف) و نقشـهـ فرونشست ساليانه برحسب ميلى متر (شكل r ب- ب) در كل دوره

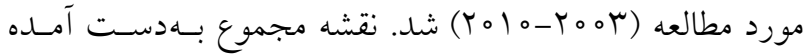

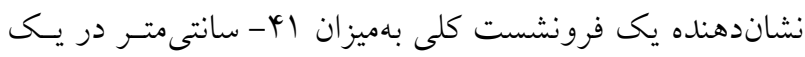



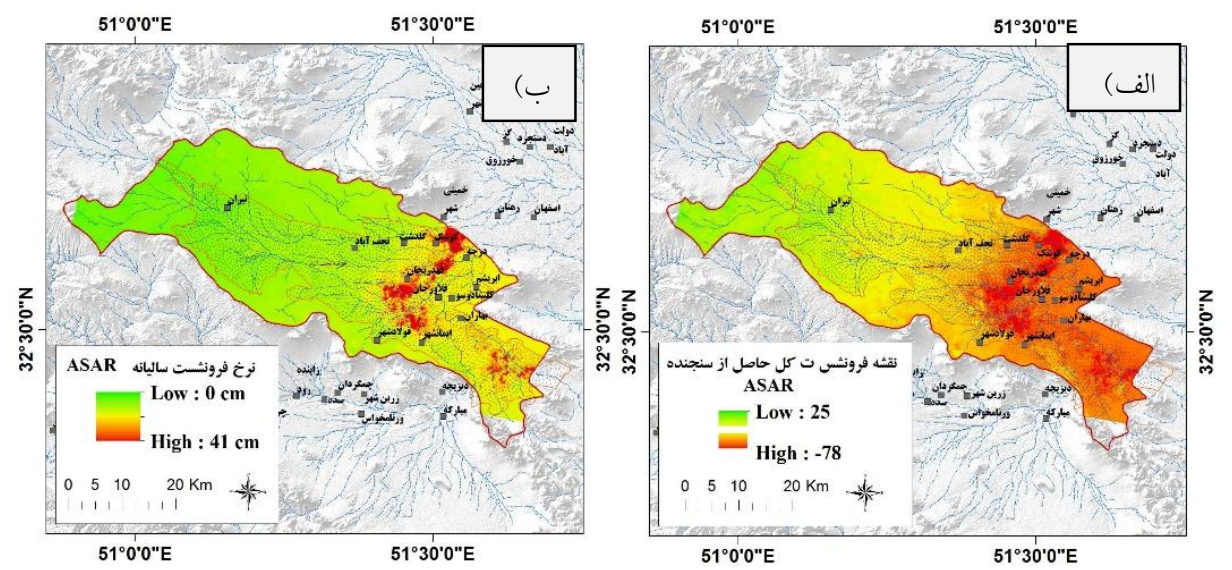

شكل r. الف) نقشه فرونشست كل حاصل از سنجنده ASAR و ب) نقشه نرخ فرونشست ساليانه حاصل از سنجنده ASAR
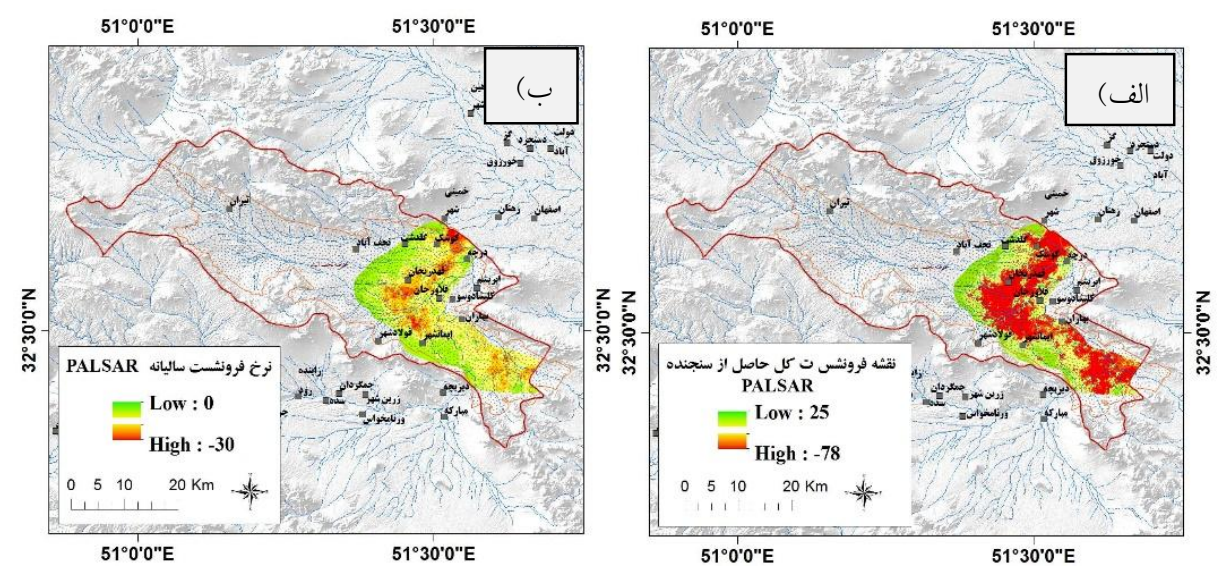

شكل f. الف) نقشه نرخ فرونشست ساليانه حاصل از سنجنده PALSAR و ب) نقشه فرونشست كل حاصل از سنجنده PALSAR

خط مبناى زمانى نيز در رتبه دوم بالاترين خط مبناهاى زمانى و

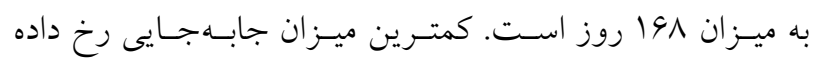

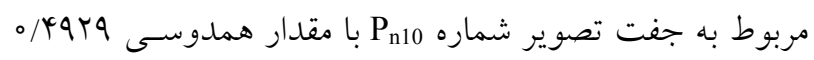

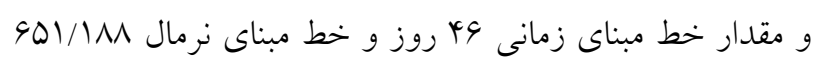

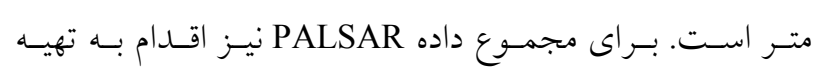
نقشههاى مجموع و ساليانه شد. نتايج حاكى از آن اسـت كـه در

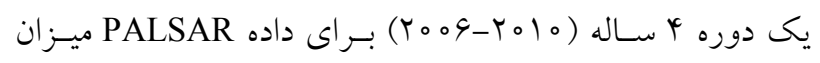

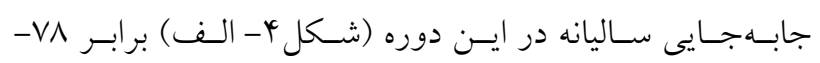

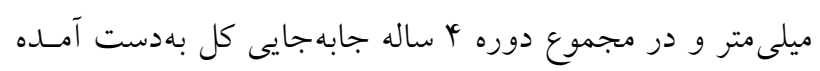

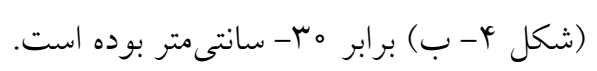

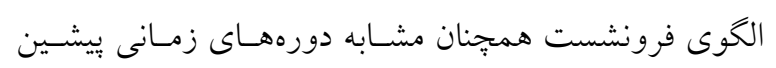

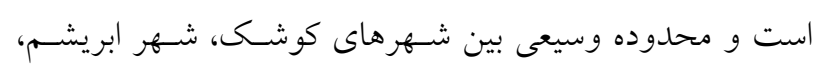

شده است. جدول ب بيانخر بيشترين ميزان جابهجايى رخ داده و مقادير همدوسى و خـط مبنـاى زمـانى و نرمـال مجموعسه داده PALSAR مطابق جدول ب همانند نتايج بهدست آمـده بـراى مجموعـه

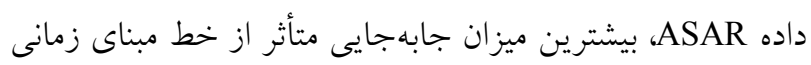
و نرمال بلند و همجينين مقادير همدوسى پيايين در مجموعه داده

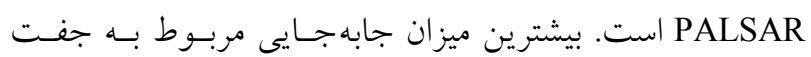
تصوير P و مقدار || - سانتى متر در طى دوره || | T T०VV/I Y/IY

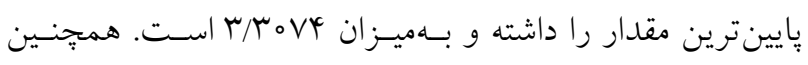
مقدار خط مبناى نرمال نيز بالاترين مقدار در بـين تمـام جفـت تصاوير را دارد و به مقدار الهو و ب49 است. علاوه بر آن مقـدار 


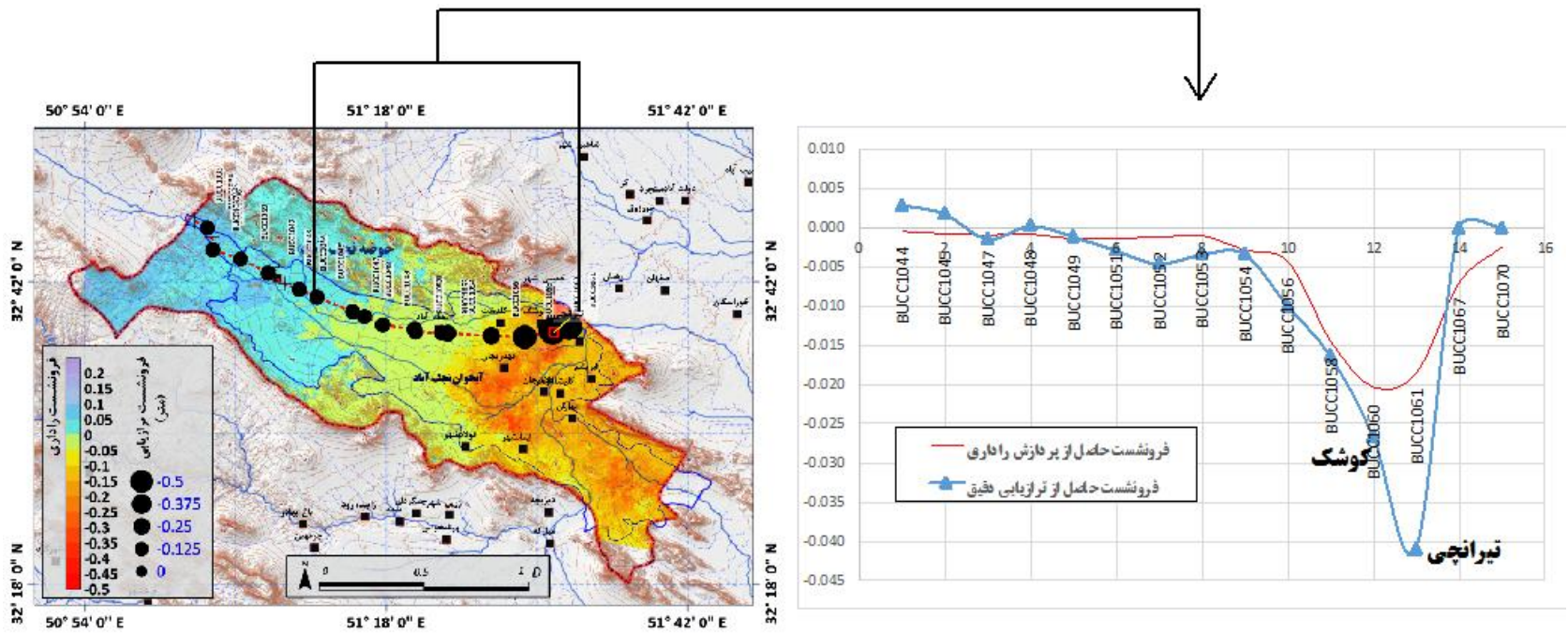

شكل هـ مطابقت فرونشست رادارى و فروننست بهدست آمده از شبكهُ بيمايش ترازيابى

بيشترين مقدار اختلاف ارتفاع منفى (فرونشست زمين) در محــدوده

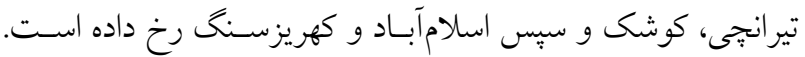
با مقايسه مكانى نتايج حاصل اندازگيرى هاى ترازيسابى و دادهــاى

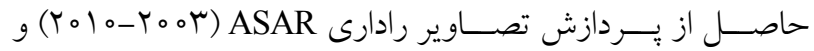

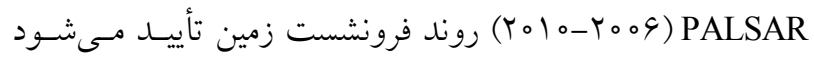

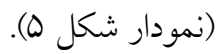
لازم به ذكر است كه با وجود تفاوت دوره زمـانى دادههـاى

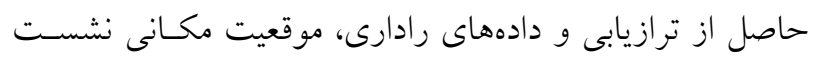

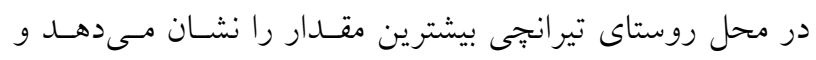

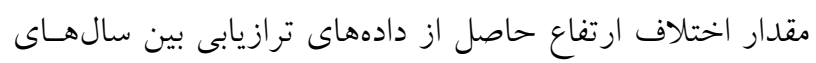

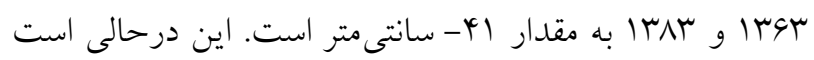

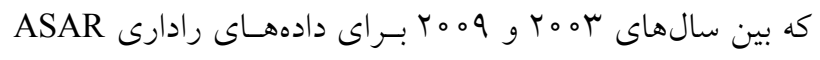

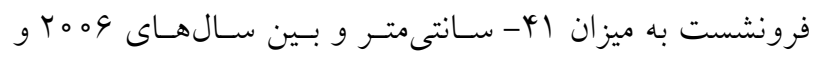

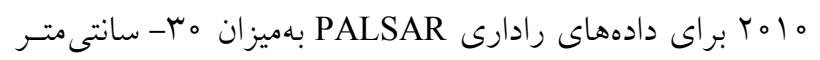

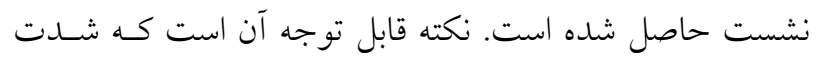

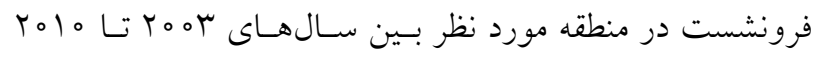

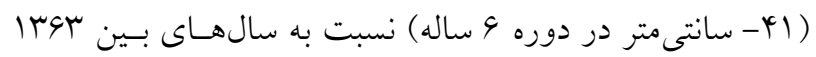

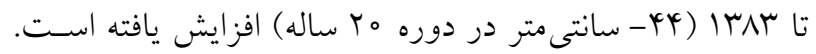
ضمن اينكه بر اساس نتايج حاصل از يردازش دادههـاى رادارى

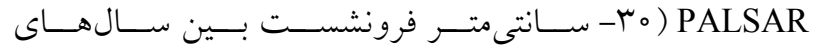

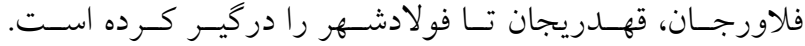

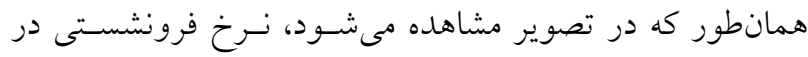
حدود ه تا V/N- سانتى متر در اين منـاطق حسادث شــده اسـت. همجنين نرخ ساليانه فرونشست با توجـهـ بـهـ بـردازش تصـاوير

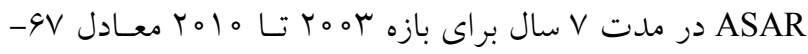
ميلىمتر و براى تصاوير PALSAR فقط در مدت ثا سال در بازه

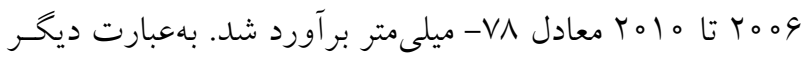
مقايسه ميزان نرخ فرونشست ASAR و PALSAR، بيـانگحر آن

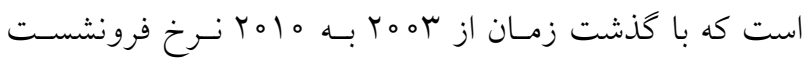
افزايش يافته است. - است

مقايسة ميزان فرونشست حاصل از يردازش تصـاوير رادارى

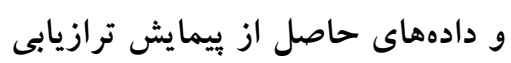

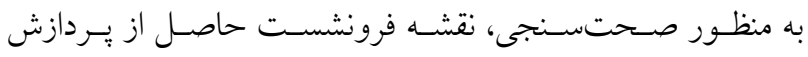

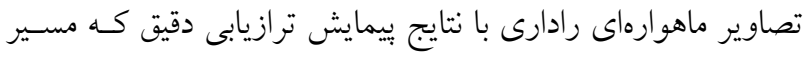
آن روى آبخوان مشخص شده است، مطابقت داده شد (نقشه شكل

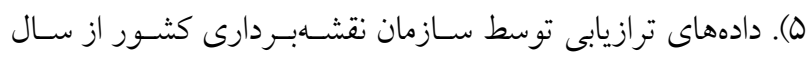

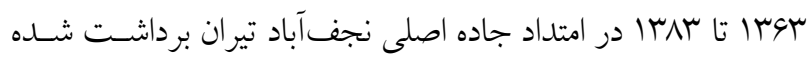

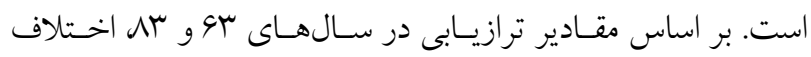

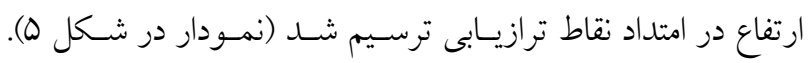




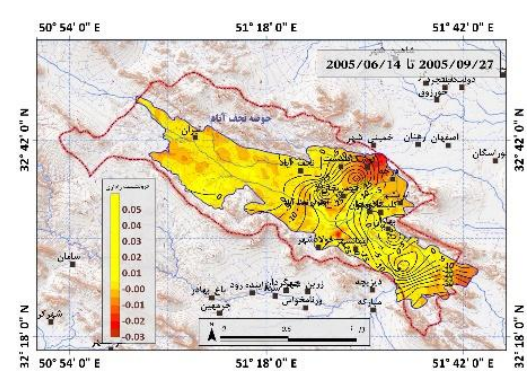

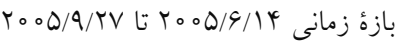

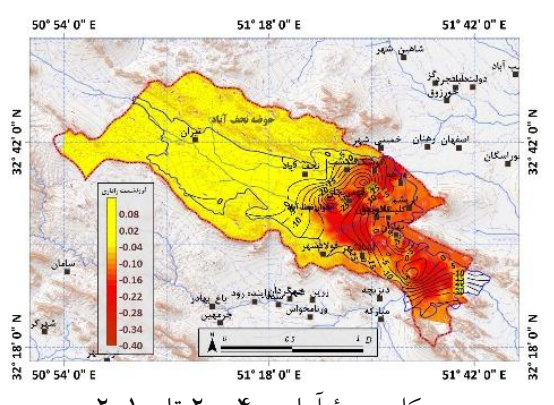

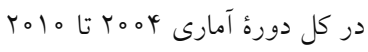

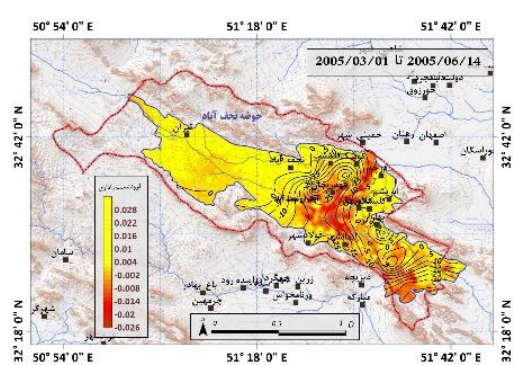

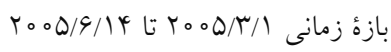

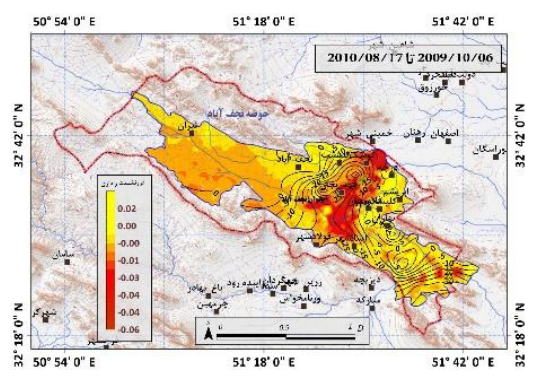

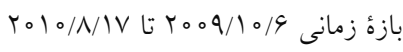

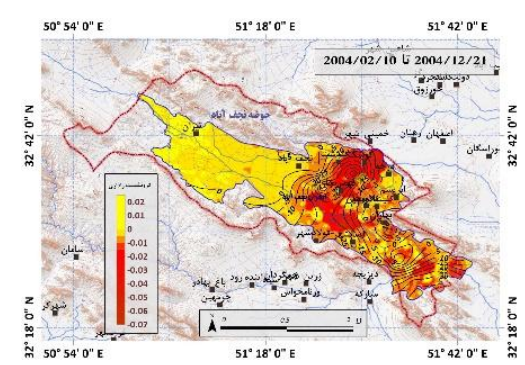

بازةٌ زمانى

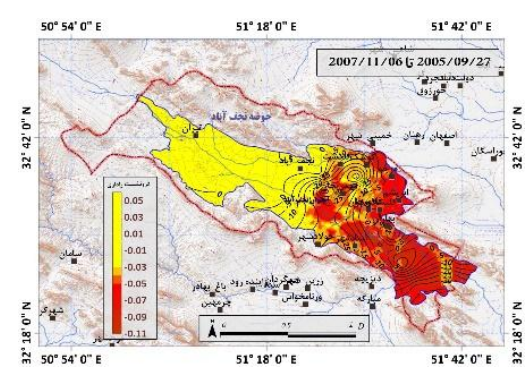

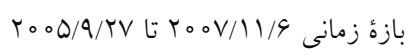

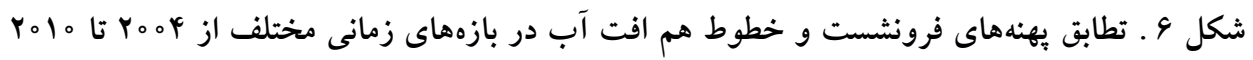

نقشههاى شكل 9 يُهنهـاى فرونشسـت آبخـوان نجـف آبـاد در

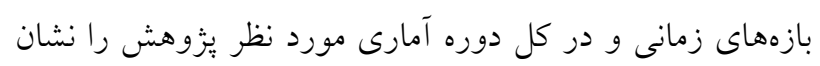

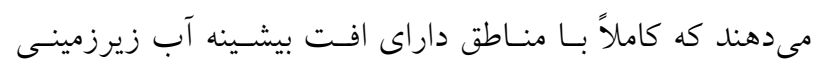

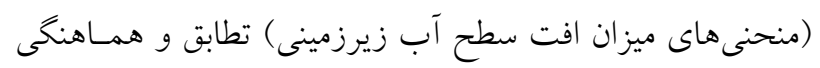

صحتسنجى و مقايسه آمارى با دادههاى موجود

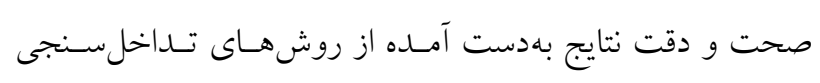

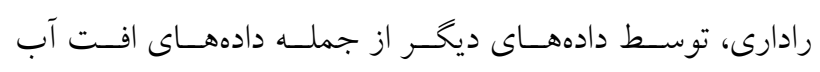

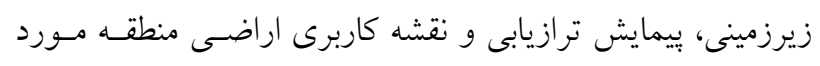
مطالعه بهصورت آمارى (همبستخى ركرسيون) مورد بررسى قـر فرار

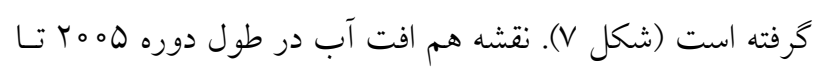

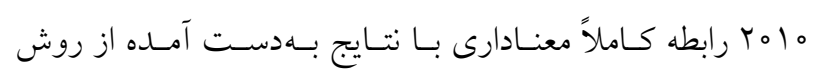

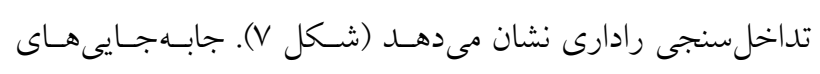

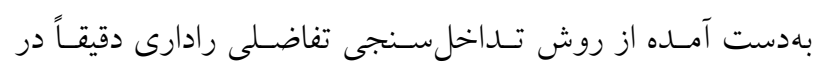

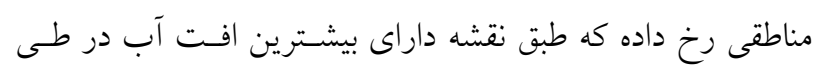

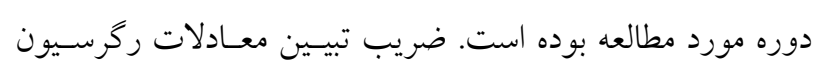

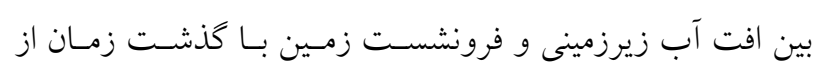

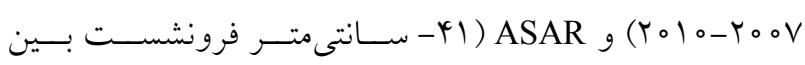

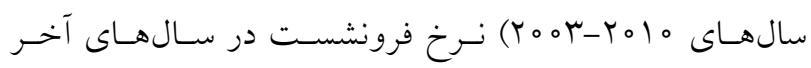

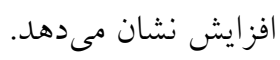

ارتباط فرونشست با تراز و افـت آب زيرزمينـى در آبخــوان نجف آباد دادههاى مكانى جاههاى مشاهدهاى آبخوان، نقشههـاى خطبوط

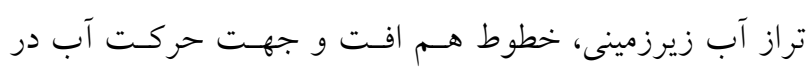

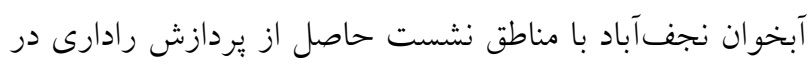

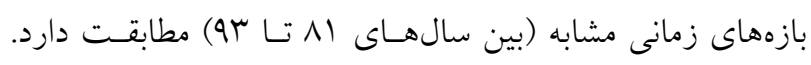

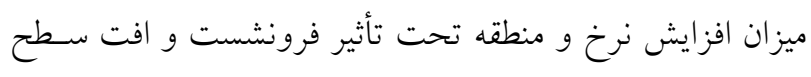

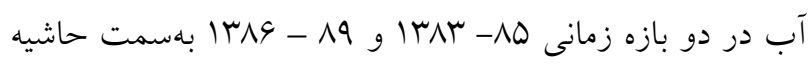

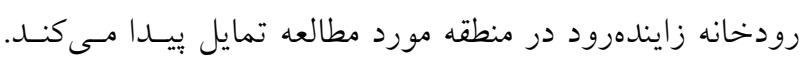

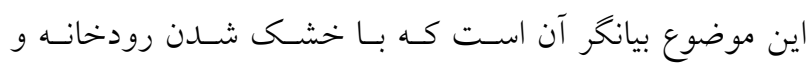

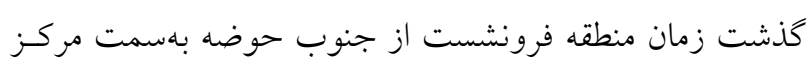

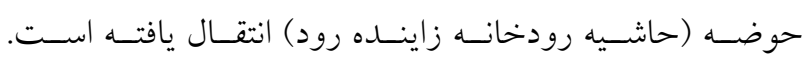

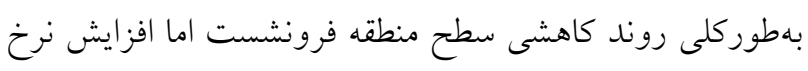

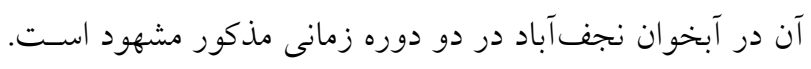




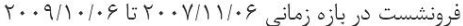

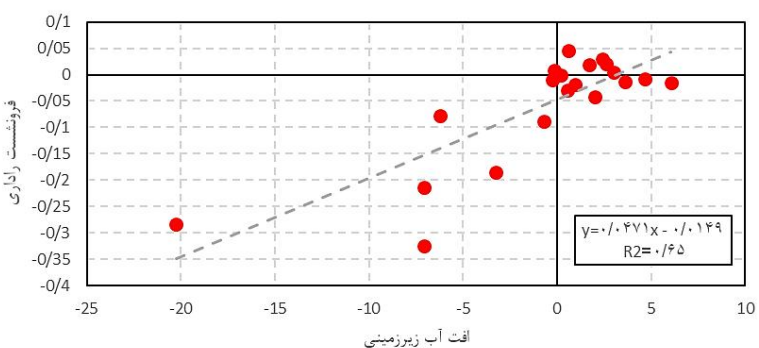

فرونشست (متوسط كل بازه هاى زمانى)

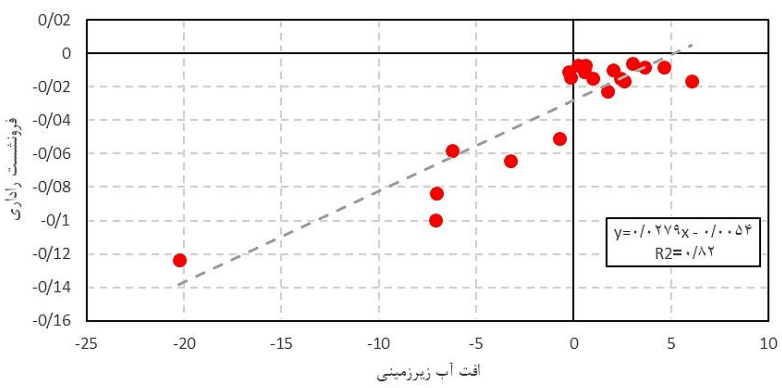

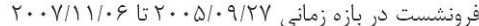

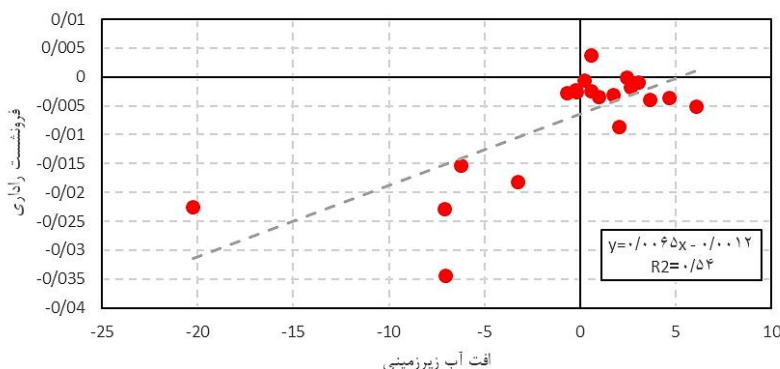

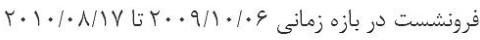

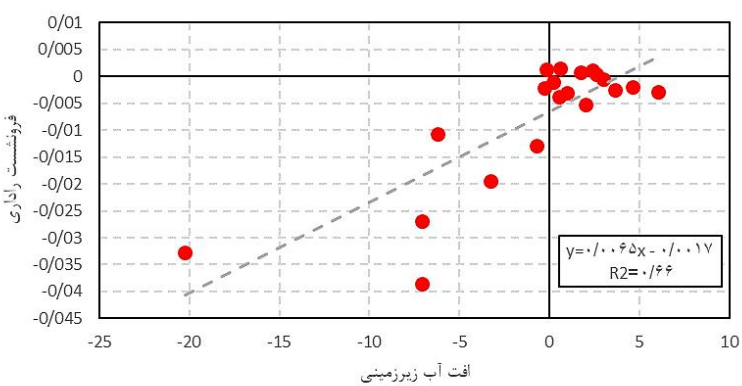

شكل V. ارتباط متوسط فرونشست در دورههاى مورد بررسى و افت آب زيرزمينى در آبخوان نجفآباد

ديخر تخمين زده شده است، كه مى توانــ بـا خسـترش بيشـر رسوبات ريزدانه در اين نواحى مرتبط باشد. ميزان فرونشست سطح زمين در برخى نواحى تا •ه سانتى متر نيز در ايسن بـازه

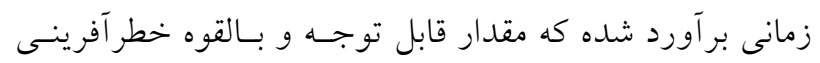
است. فرونشست قابل ملاحظهاى نيز در محل خروجى آبخوان واقع در شرق و جنوب شرق بيربكران مشـاهده مسىشـود. در اين ناحيه نيز رسوبات ريزدانه به نسبت فراوانى بيشترى دارند. در نواحى اطراف رودخانه زايندهرود ميزان فرونشست بهدليـل تغذيه آبخوان به توسط رودخانه، كاهش يافته است. شكل ه ا نشاندهنده نقشه ميـزان هــايت الكتريكىى (EC) آب زيرزمينى در سال بوسا است. تطابق قسمتى از آبخوان كـه

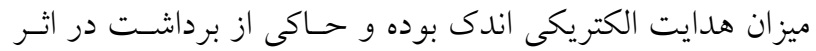

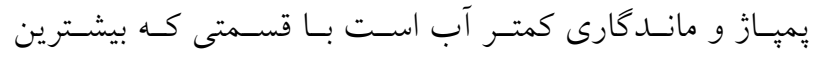
فرونشست را متحمل شده بلهوضوح مشاهله مىشود. در حوالى رودخانه زايندهرود بهدليل تغذيه ميزان EC و فرونشست كاهش

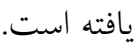

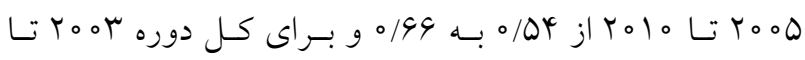

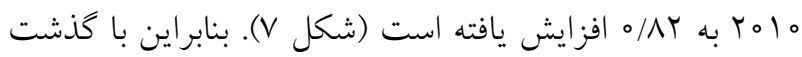
زمان، همبستكى بـين فرونشسـت زمسين و افـت آب زيرزمينى افزايش يافته و برداشت آب زيرزمينى عامـل مـؤثر و اصـلى در فرونشست زمين در اين منطقه است. بهدليل دسترسى به داده رادارى مناسب در بازه زمانى بـين

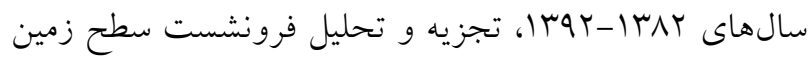
در اثر برداشت بى رويه آب زيرزمينسى تنهـا بـه ايسن ده سـال منحصر شده است (شكل ^). بدين منظور نقشه افت تجمعسى سطح آب زيرزمينى در بازه زمانى برسا تا بوسا ترسيم شـده

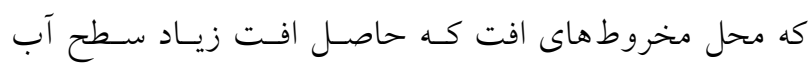
زيرزمينى است در اين نقشه هويدا است. حداكثر افت سـطح آب زيرزمينى در محل مخروطهاى افت تجمعى به حسـود متر در اين بازه زمانى بالغ مىشود. شكل 9 فرونشست تجمعى

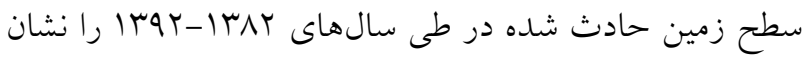
مىدهد. طبق اين نقشه ميزان فرونشست در قسـمت شـرق و جنوب شرق شهر نجفَآباد بـهمراتـب بيشـتر از قسـمتهـاى 


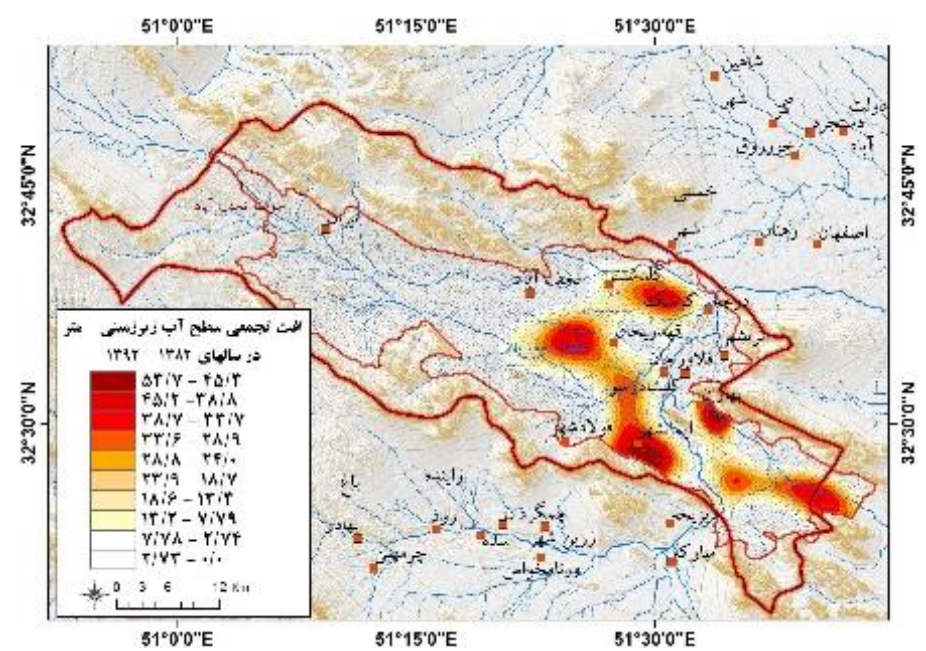

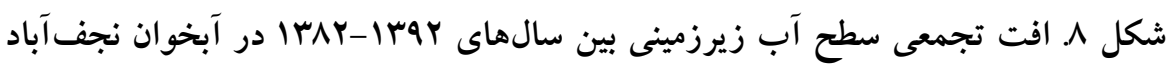

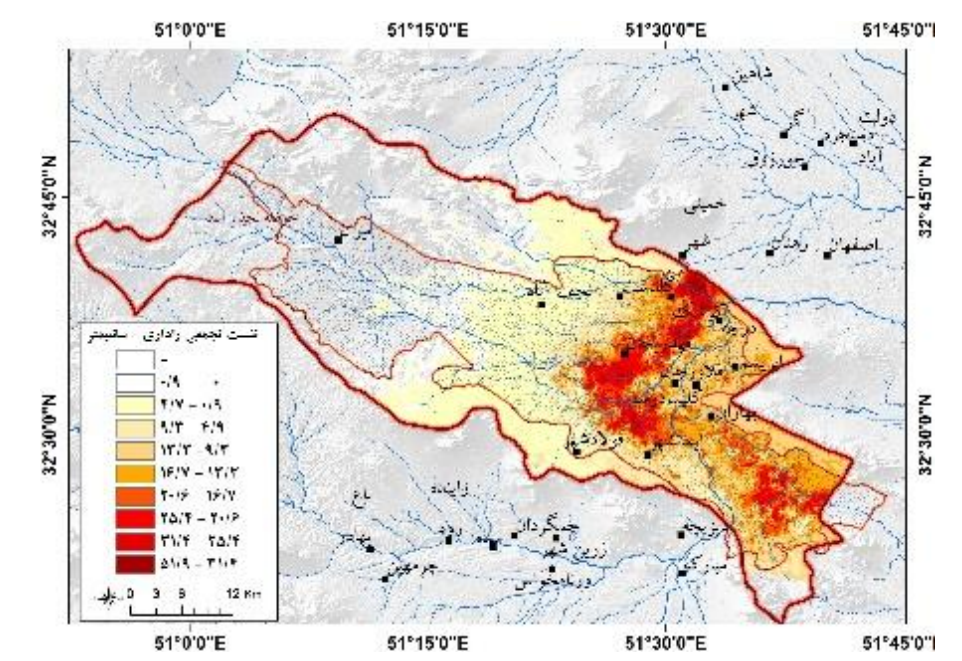

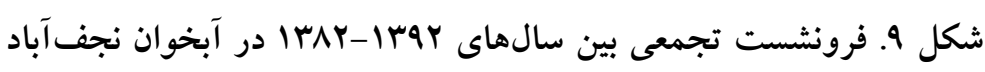

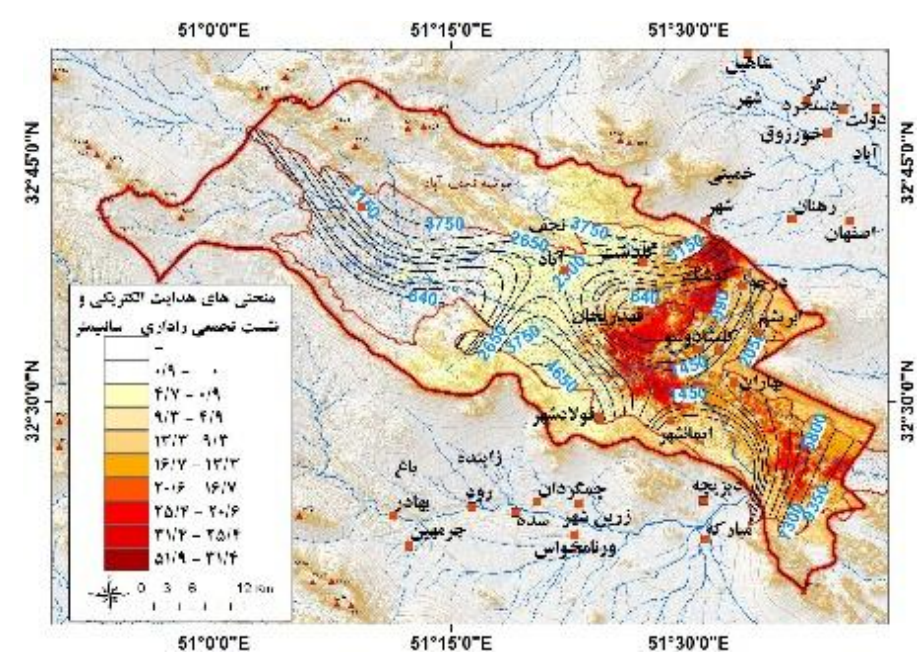

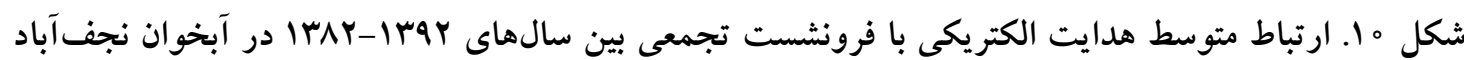




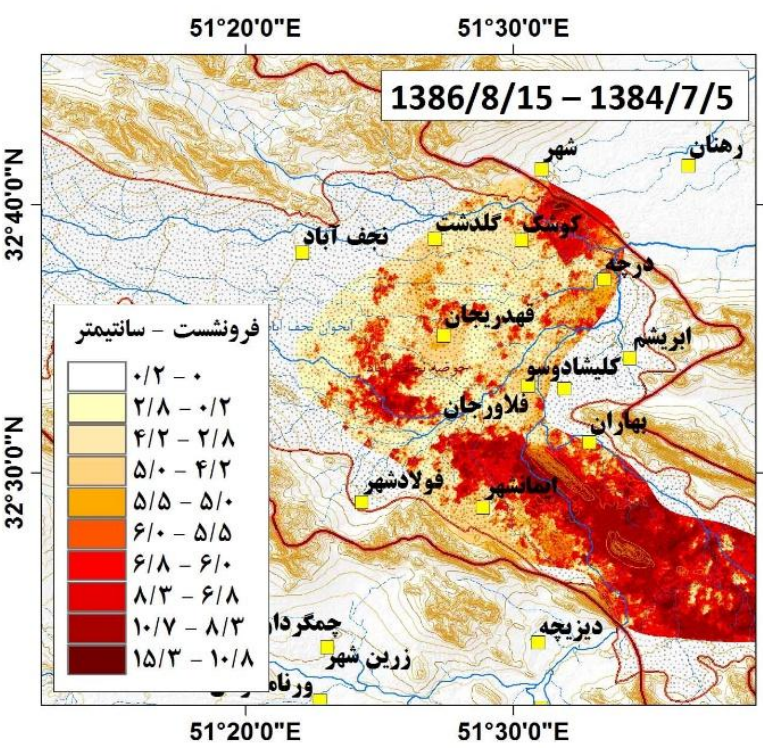

(ب)

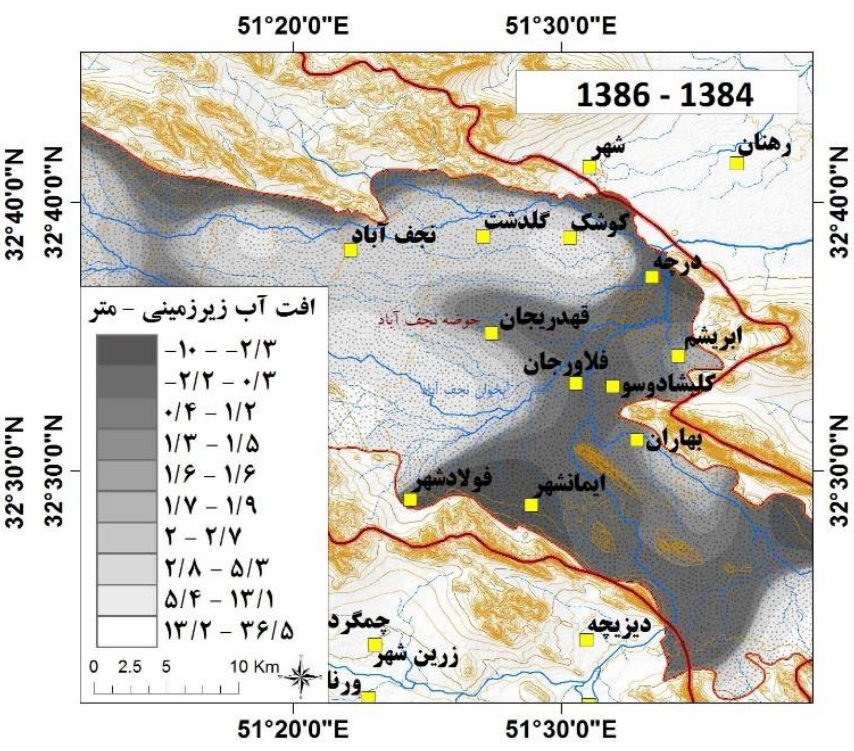

(الف)

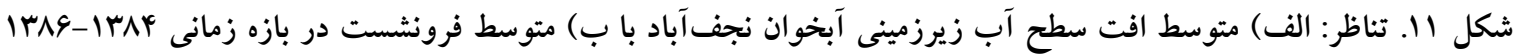

فرونشست را با آن مرتبط دانست. از اينرو نقشه كاربرى اراضى

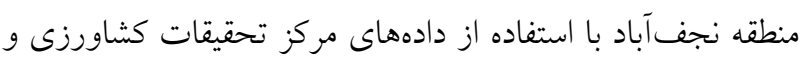

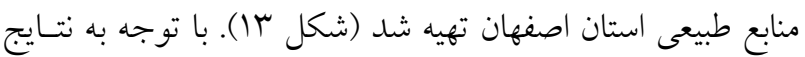

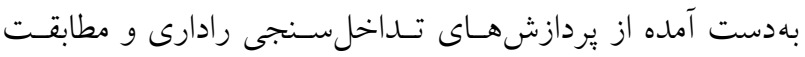

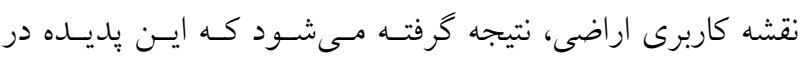

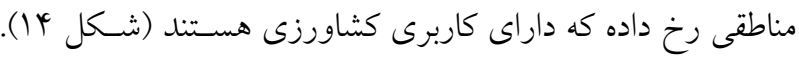

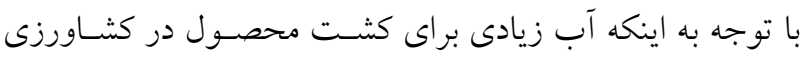

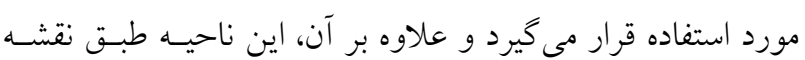

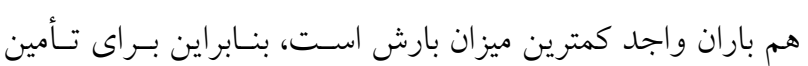

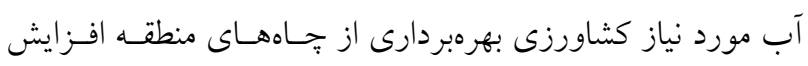
يافته، بهطورى كه اين ميزان از بهرهبردارى در بعضى موارد بيشتر

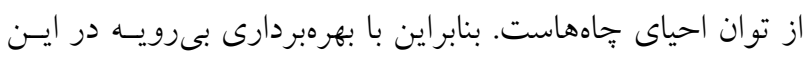
بخش شاهد افت سطح زاههاى منطقه در گذر زمان شــده و ايسن

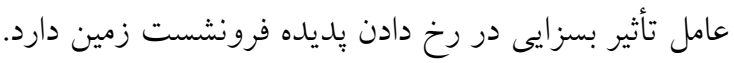

\section{نتيجه گيرى}

در اين يُزوهش يديده فرونشست در دشت نجف آباد اصفهان بـا

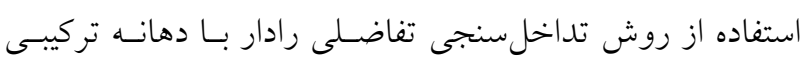

بهمنظور اثبات هرجه بيشتر ارتباط فرونشست زمين بــا افت سطح

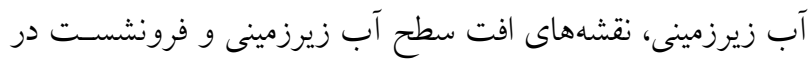

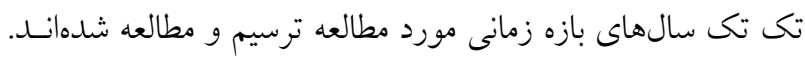
ميزان فرونشست متناظر با مقدار افت سـطح آب زيرزمينسى نوسـان

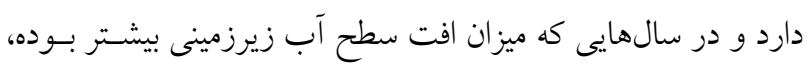

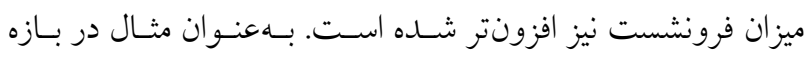

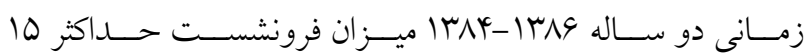
سانتىمتر تخمين زده شده است (شكل (1)). درصورتى كه در بـازه

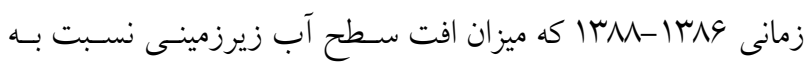

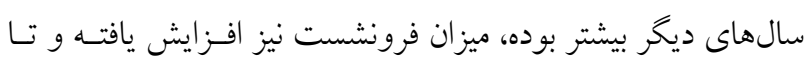

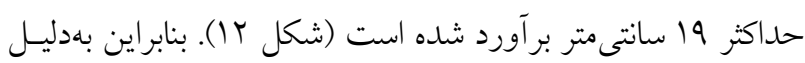

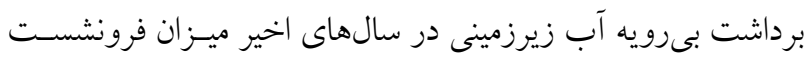

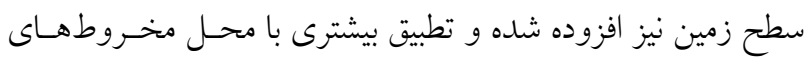
افت ايجاد شده در سطح آب زيرزمينى بيدا كرده است.

بررسى ارتباط فرونشينى، افت و كاربرى ارضسى در آبخــوان نجف آباد كاربرى اراضى يكسى از فاكتورهـايى اسـت كـه مسىـــوان بِديـــه 

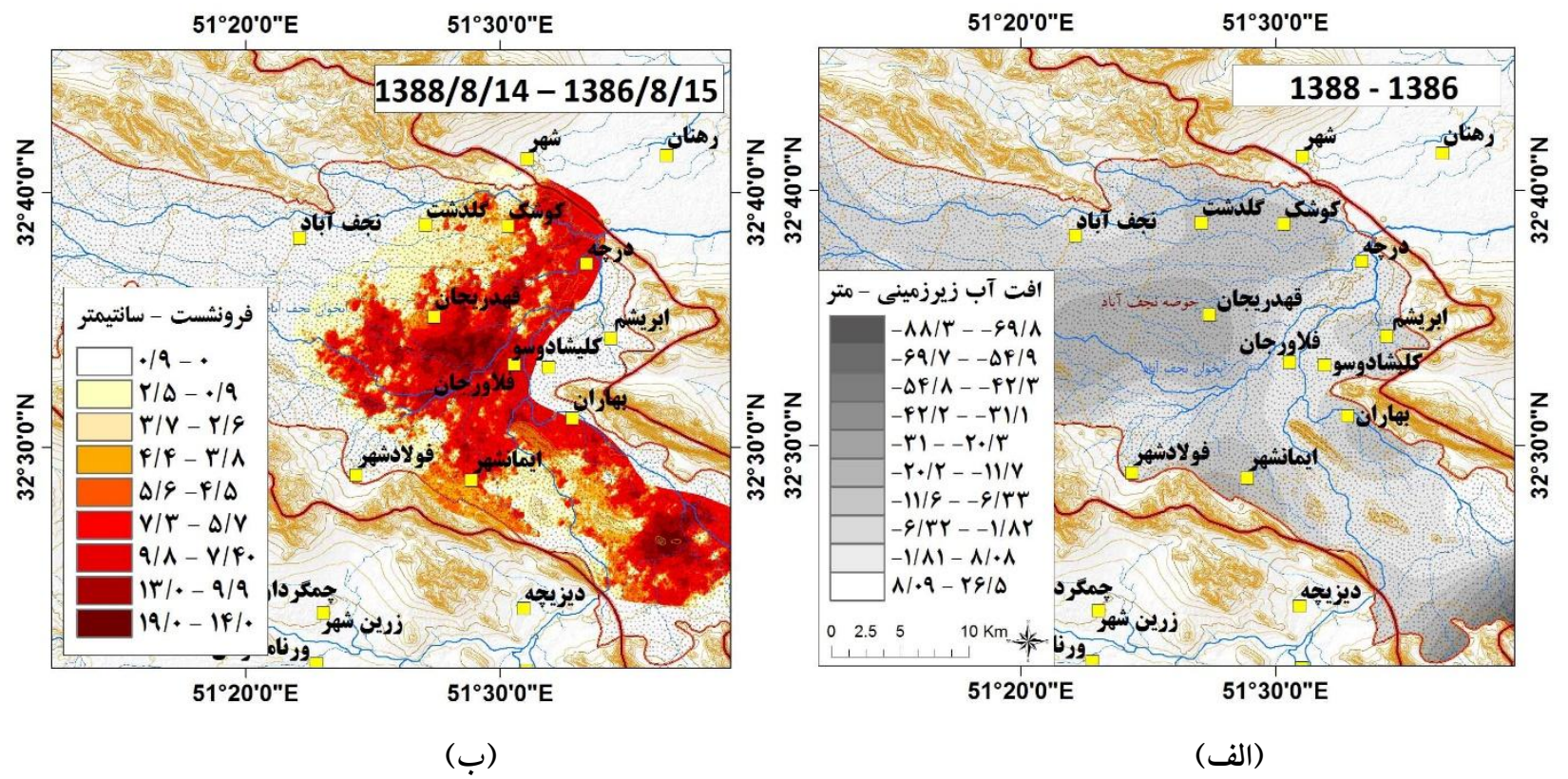

شكل ץا. تناظر: الف) متوسط افت سطح آب زيرزمينى آبخوان نجفآباد با ب) متوسط فرونشست در بازه زمانى

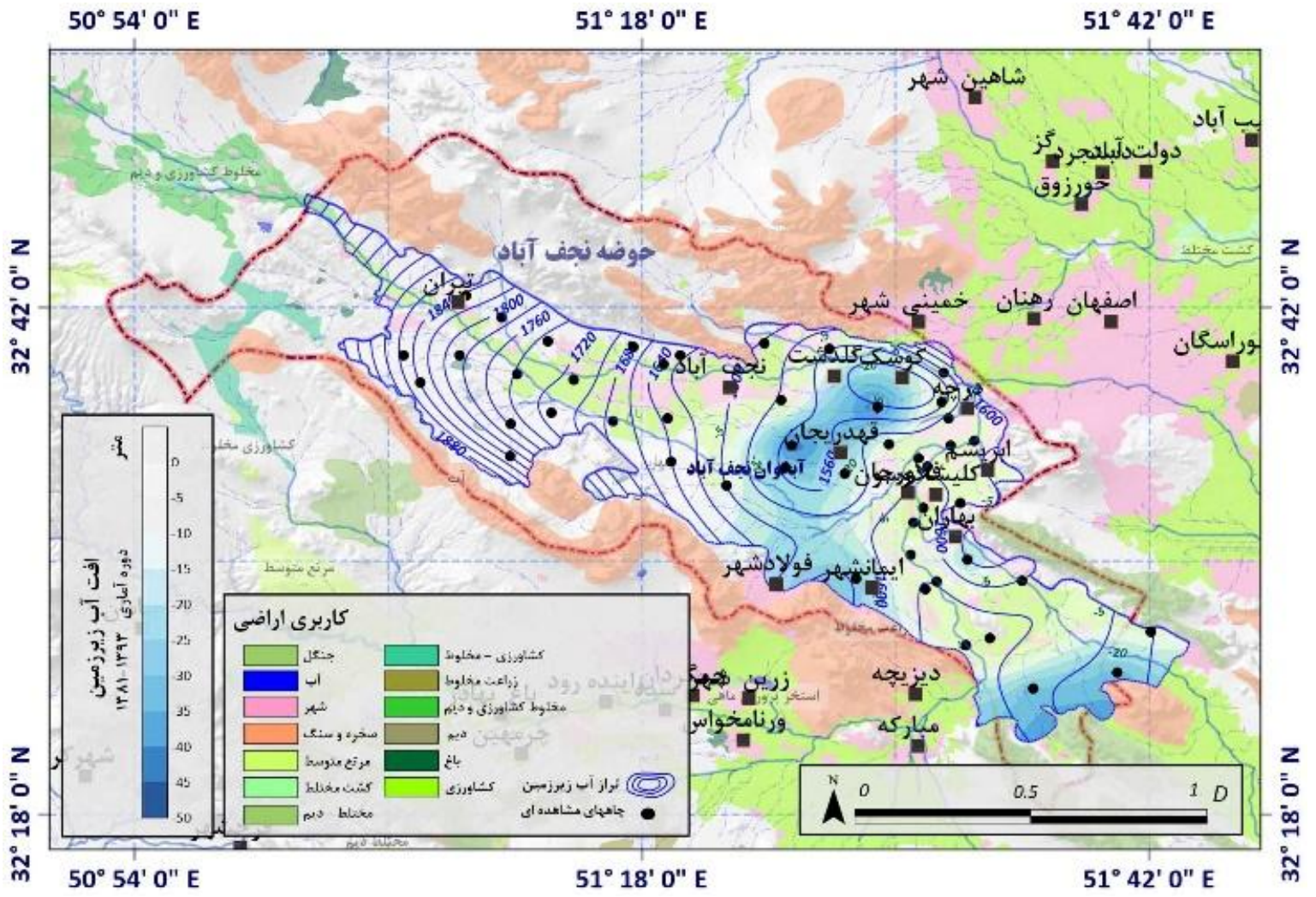

شكل rا. كاربرى زمين، خطوط تراز و هم افت آب زيرزمينى 

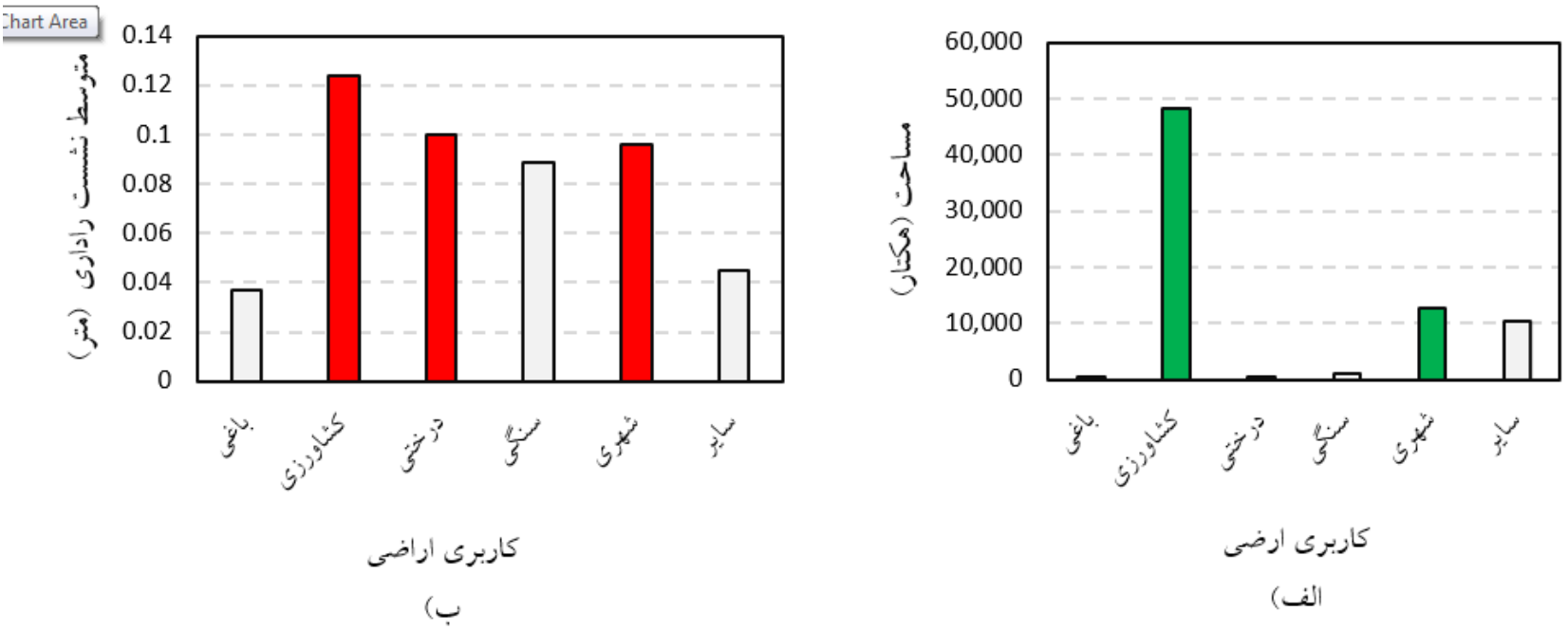

شكل \& ا. الف) مساحت ردههاى مختلف كاربرى ارضى و ب) متوسط فرونشست رادارى در ردههاى مختلف كاربرى ارضى

سانتىمتر در فريم كامل تصوير ASAR و بهمقـدار ه/ه- سـانتى

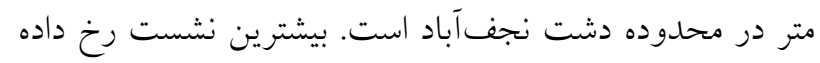

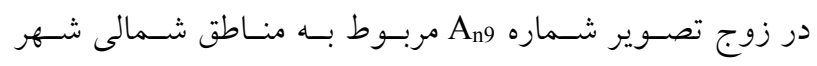

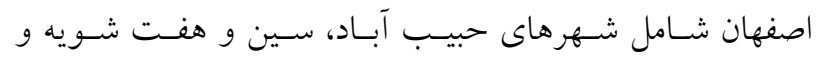
همجنين مربوط به دشت مهيار در جنوب شرقى شهر اصفهان و

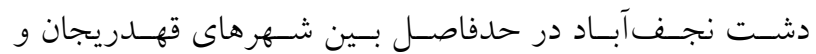
فلاورجان است. در مورد تصاوير سـنجنده PALSAR بيشـترين فرونشسـت

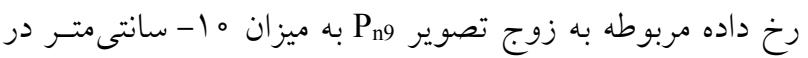

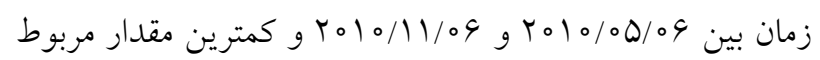

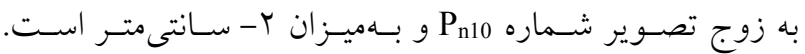

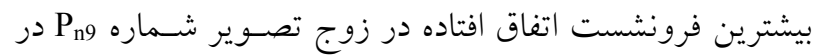

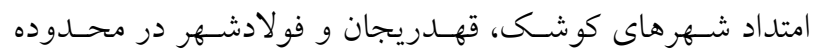
دشت نجف آباد است. با درنظـر كـرفتن تمـامى نقشـهــاى حاصـل از «ـردازش دادههاى هر دو سنجنده ASAR و PALSAR، بيشترين ميـزان فرونشسـت در شـهرهاى تيرانجـى، كوشـك، قهــريجان و

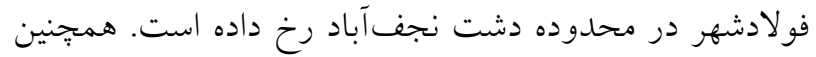
مقادير فرونشست حاصل از دادههاى ترازيابى دقيق با ميزان و كُتره فرونشست بهدست آمـده از بـردازش دادههـاى رادارى

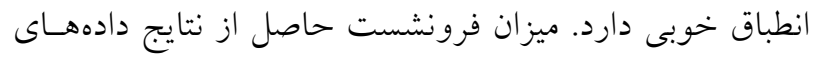

بررسى شده اسـت. بـــين منظـور از دو مجموعـه (DInSAR) داده شــامل تعـــاد بץ تصــوير از ســنجنده ASAR مـــاهواره ENVISAT در باند C و كذر نزولى با قطبيت HH و تعـداد rا تصوير از سـنجنده PALSAR مـاهواره ALOS در بانــ L و در كذر صعودى با قطبيت HH استفاده شده اسـت. از بسين جفـت

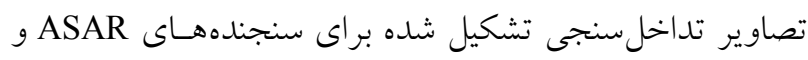

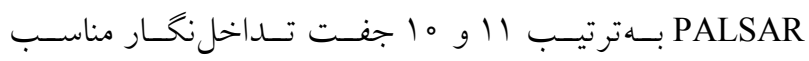

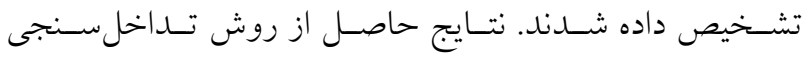
تفاضلى (DInSAR) نشان مىدهد كه فرونشست در منطقه مورد

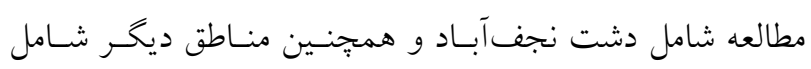

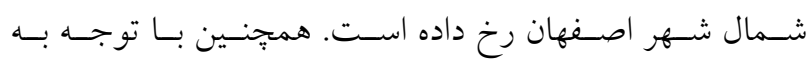

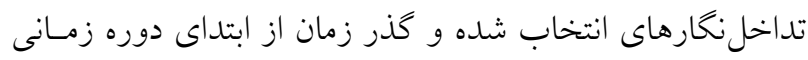

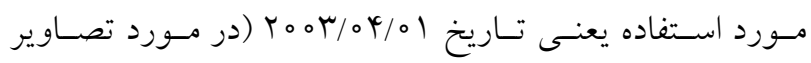

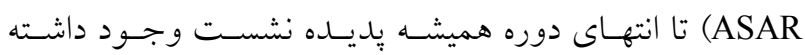

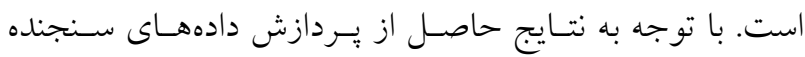

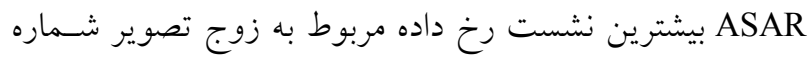
- YY

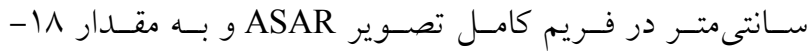
سانتى متر در محدوده دشت نجفآباد اسـت. هميجنسين كمتـرين

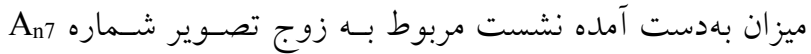

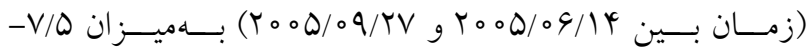




$$
\begin{aligned}
& \text { اراضسى، منـاطق كشــاورزى بــا منـاطق افـت آب زيرزمينسى و } \\
& \text { ترازيابى در محدوده تيرانجى به ميزان أ|- سانتى متر است كه } \\
& \text { فرونشست انطباق خوبى نشان مىدهد كه اين خود دليلى بـر } \\
& \text { مقادير حاصل از يردازش دادههاى رادارى را تأييد مى كند. } \\
& \text { افزايش برداشت آب زيرزمينى بـهمنظـور مصـارف كشـاورزى } \\
& \text { بر اساس يــردازشهـاى رادارى انجـام گرفتـه، فاكتورهـاى } \\
& \text { همدوسى و خط مبناى زمـانى و نرمـال تـأثير زيـادى در نتـايج } \\
& \text { بهدست آمده از روش تداخلسنجى دارند. بهطورى كه هر زمان } \\
& \text { سياسگزارى } \\
& \text { اين سه فاكتور از حالت استاندارد و آسـتانه خـود فراتـر رونــد، } \\
& \text { بلدين صورت كه همدوسى كاهش و خط مبناى زمانى و نرمـال }
\end{aligned}
$$

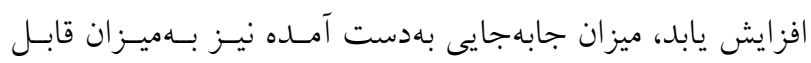

$$
\begin{aligned}
& \text { توجهى افزايش خواهل يافت. بدين ترتيـب در صـورت وجـود } \\
& \text { جنين حالاتى ممكـن اسـت نتـايج حاصـل از واقعيـت موجـود } \\
& \text { فاصله بخيرد و گمراه كننده باشد. }
\end{aligned}
$$

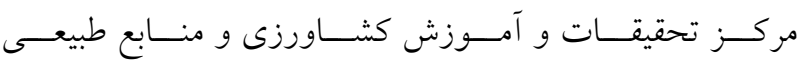

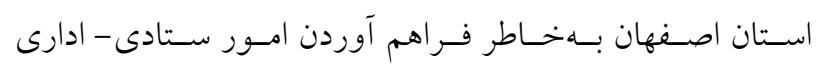

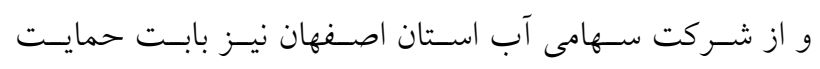

$$
\begin{aligned}
& \text { مـالى يــزوهش (ESW94021) صـميمانه تشـكر و قـدردانى } \\
& \text { مى شود. } \\
& \text { همجنين افزايش ميزان هدايت الكتريكى آب زيرزمينسى (EC) } \\
& \text { بـا محـل هــاى مخــروطهـاى افـت آب زيرزمينسى و افـزايش } \\
& \text { فرونشست انطباق دارد. همجزين بـا توجسه بـه نقشـه كـاربرى }
\end{aligned}
$$

منابع مورد استفاده

1. Alami, A. 2002. Investigating the causes of land subsidence in the Yazd-Ardakan plain. Proceedings of the 3rd International Conference on Geotechnical Engineering and Soil Mechanics, Tehran.

2. Amighpey, M., S. Arabi, A. Talebi and Djamour. 2006. Elevation changes of the precise leveling tracks in the Iran leveling network. Scientific Report Published in National Cartographic Center (NCC) of Iran, Tehran, Iran.

3. Amiri, M. 2006. Relationship between sinkholes of Famenin-Kabudrahang-Ghahvand plain with bed rock of the area. Geosciences 15(58): 134-147.

4. Anderssohn, J., H. Wetzel, T. R. Walter, M. Motagh, Y. Djamour and H. Kaufmann. 2008. Land subsidence pattern controlled by old alpine basement faults in the Kashmar Valley, northeast Iran: results from InSAR and levelling. Geophysical Journal International 174(1): 287-294. DOI: http://doi.org/10.1111/j.1365-246X.2008.03805.x.

5. Ashrafianfar, N., W. Busch, M. Dehghani and P. Haghighatmehr. 2010. Differential SAR interferometric technique for land subsidence monitoring due to ground water exploitation in the Hasthgerd. Proceeding of Fringe 2009 Workshop, Frascati, Italy, ESA SP-677.

6. Buckley, S. J. and J. P. Mills. 2002. Synergy of GPS, Digital Photogrammetry and InSAR in Coastal Enviroments, Miami, Florida. USA.

7. Chamundeeswari, V. V., D. Singh, K. Singh and W. Wiesbeck. 2008. A Critical Analysis to Generate Change Detection Map using SAR Interferometry for Land Subsidence Monitoring of New Orleans City of USA. IEEE Xplore, IGARSS 2008 - 2008 IEEE International Geoscience and Remote Sensing Symposium. 518-521. 10.1109/IGARSS.2008.4779772.

8. Davoodijam M., M. Motagh and M. Momeni. 2015. Land Subsidence in Mahyar Plain, Central Iran, Investigated Using Envisat SAR Data. In: Kutterer, H., F. Seitz, H. Alkhatib and M. Schmidt. (Eds.), The 1st International Workshop on the Quality of Geodetic Observation and Monitoring Systems (QuGOMS'11). International Association of Geodesy Symposia, Vol 140. Springer, Cham 
9. Dehghani, M., M. J. V. Zoej, I. Entezam, A. Mansourian and S. Saatchi. 2009a. InSAR onitoring of progressive land subsidence in Neyshabour, northeast Iran. Geophysical Journal International 178 (1): 47-56.

10. Dehghani, M., M. J. V. Zoej, S. Saatchi, J. Biggs, B. Parsons and T. Wright. 2009b. Radar Interferometry Time Series Analysis of Mashhad Subsidence. Journal of the Indian Society of Remote Sensing 37(1): 147-156.

11. Dehghani, M., M. J. ValadanZoej, I. Entezam, S. Saatchi and A. Shemshaki. 2010. Interferometric measurements of ground surface subsidence induced by overexploitation of groundwater. Journal of Applied Remote Sensing 4(041864): 1-15.

12. Dehghan-Soraki, Y., S. K. Saha and M. Kumari. 2013. A modified polarimetric decomposition for applicability in complex agricultural environment, International Archives of the Photogrammetry, Remote Sensing and Spatial Information Sciences, Volume XL-1/W3, 2013 SMPR 2013, 5-8 October 2013, Tehran, Iran.

13. Engelbrecht, J. and M. R. Inggs. 2016. Coherence optimization and its limitations for deformation monitoring in. dynamic agricultural environments. IEEE Journal of Selected Topics in Applied Earth Observations and Remote Sensing 9(12): 5647-5654.

14. Fatemi Aghda, M., S. M. Nakhaei, M. Baitollahi and A. R. Aliyari. 2001. Study of cause of sinkhole development in Hamedan central plain. Proceeding of Second Iranian Conference of Engineering Geology and Environment, Tehran 2: 693-701.

15. Ferretti, A., A. Monti-Guarnieri, C. Prati, F. Rocca and D. Massonnet. 2007. InSAR Principles - Guidelines for SAR Interferometry Processing and Interpretation. ESA Training Manual. 19.

16. Fiaschi, S., S. Tessitore, R. Bonì, D. Di Martire, V. Achilli, S. Borgstrom, A. Ibrahim, M. Floris, C. Meisina and M. Ramondini. 2017. From ERS-1/2 to Sentinel-1: Two decades of subsidence monitored through a-dinsar techniques in the ravenna area (Italy). GIS Science \& Remote Sensing 54(3): 305-328. doi: 10.1080/15481603.2016.1269404.

17. Gabriel, A. K. and R. M. Goldstein. 1988. Crossed orbit interferometry: theory and experimental results from SIRB. International Journal of Remote Sensing 9(5): 857-872.

18. Ghazifard, A., E. Akbari, K. Shirani and H. Safaei. 2017. Evaluating land subsidence by field survey and D-InSAR technique in Damaneh City, Iran. Journal of Arid Land 9: 778-789. https://doi.org/10.1007/s40333-017-0104-5

19. Hu, R. L., Z. Q. Yue, L. C. Wang and S. J. Wang. 2004. Review on current status and challenging issues of and subsidence in china. Engineering Geology 76: 65-77.

20. Jacob, C. E. 1939. Fluctuations in artesian pressure produced by passing railroad trains as shown in a well on Long Island, New York. Transactions, American Geophysical Union 20: 666-674.

21. Lin, Q., J. F. Vesecky and H. A. Zebker. 1992. New approaches in interferometric SAR data processing. IEEE Transactions on Geoscience and Remote Sensing 30: 560-567.

22. Rosen, P. A., S. Hensley, I. R. Joughin, F. K. Li, S. N. Madsen, E. Rodríguez and R. M. Goldstein. 2000. Synthetic Aperture Radar Interferometry, Proceedings of the IEEE Xplore, 88, 333-382. DOI: 10.1109/5.838084.

23. Mirmohammad Sadeghi, M., B. Ebrahimi and M. Pasandi. 2018. Groundwater depletion and stream-aquifer interaction (case study: The Najafabad aquifer in Zayandehroud river basin). Journal of Water and Soil Science (Science and Technology of Agriculture and Natural Resources) 22(2): 107-125.

24. Motagh, M., J. Klotz, F. Tavakoli, Y. Djamour, S. Arabi, H. Wetzel and J. Zschau. 2006. Combination of precise leveling and InSAR data to constrain source parameters of the $\mathrm{Mw}=6.5,26$ December 2003 Bam earthquake. Pure and Applied Geophysics 163(1): 1-18. DOI: http://doi.org/10.1007/s00024-005-0005-y.

25. Motagh, M., Y. Djamour, T. R. Walter, H. Wetzel, J. Zschau and S. Arabi. 2007. Land subsidence in Mashhad Valley, northeast Iran: results from InSAR, levelling and GPS. Geophysical Journal International 168(2): 518-526. DOI: http://doi.org/10.1111/j.1365-246X.2006.03246.x.

26. Mousavi, S. M., A. Shamsai, M. H. E. Naggar and M. Khamehchiyan. 2001. A GPS-based monitoring program of land subsidence due to ground water withdrawal in Iran. Cannadian Journal of Civil Engineering 28(3): $452-464$.

27. Parker, G. G. and V. T. Springfield. 1950. Effects of earthquakes, rains, tides, winds, and atmospheric pressure changes on the water in geological information of southern Florida. Economic Geology 45: 441-460.

28. Prati, C. and F. Rocca. 1994. Use of the spectral shift in SAR interferometry. Second ERS-1 Symposium-Space at the Service of our Environment, Hamburg, Germany, 11-14 October 1993, ESA SP-361.

29. Rosen, P. A., S. Hensley, I. R. Joughin, F. K. Li, S. N. Madsen, E. Rodríguez and R. M. Goldstein. 2000. Synthetic Aperture Radar Interferometry. Proceedings of the IEEE, 88: 333-382.

30. Sedighi, M., S. Arabi, H. R. Nankali, M. Amighpey, F. Tavakoli, A. Soltanpour and M. Motagh. 2010. Subsidence Detection Using InSAR and Geodetic Measurment in North-West of Iran. Proceeding 'Fringe 2009 Workshop', Frascati, Italy. Sens. 9: 857-872.

31. Sharifikia, M. 2009. Fault rupture Identification in Recent Satellite Imagery. Second International Conference on Geo-information Technology for Natural Disaster, Thailand.

32. Shemshaki, A. and M. J. Bolourchi. 2006. Land subsidence in the Tehran plain and the factors influencing its formation. 24th National Geosciences Congress. 
33. Singhory, V., K. E. Mattar and A. L. Gray. 1998. Landslide characterisation in Canada using interferometric SAR and combined SAR and TM images. Advances in Space Research 21(3): 465-476.

34. Sun, H., D. Grandstaff and R. Shagam. 1999. Land subsidence due to groundwater withdrawal: Potential damage of subsidence and sea level rise in southern New Jersey, USA. Environmental Geology 34: 290-296.

35. Toufigh, M. M. and B. Shafbeisabet. 1995. Prediction of future land subsidence in Kerman, Iran, due to groundwater withdrawal. Proceedings of the Fifth International Symposium on Land Subsidence, The Hague, IAHS Publ, No. 234.

36. Wempen, J. M. and M. K. McCarter. 2017. Comparison of L-band and X-band differential interferometric synthetic aperture radar for mine subsidence monitoring in central Utah. International Journal of Mining Science and Technology 27: 159-163. doi:10.1016/j.ijmst.2016.11.012.

37. Zayandab Consulting Engineers. 2015. Updating the water resources balance of the Gavkhuni water basin during 2010-2011 water year, Vol. 5: Evaluation of water resources, Appendix 6: Report on the water resources balance in the Najafabad water basin (Code 4206). 


\title{
Assessment of Land Subsidence in the Najafabad Plain Using the Differential Synthetic Aperture Radar Interferometry (DInSAR) Technique
}

\author{
K. Shirani ${ }^{1 *}$, M. Pasandi² and B. Ebrahimi ${ }^{3}$
}

(Received: May 4-2020 ; Accepted: August 24-2020)

\begin{abstract}
Land subsidence as a hydrogeomorphology event is currently occurring dangerously in many plains of the country due to uncontrolled groundwater extraction from water bearing layers, and accordingly monitoring and studying this phenomenon seems to be necessary. In this study, land subsidence rate of the Najafabad aquifer was determined through the Differential Radar Interferometry (DInSAR) processing of the ASAR and PALSAR radar data and the results were validated by comparying with the differential leveling and groundwater level drowdown data. Processing of the ASAR sensor data estimates the land subsidence in the Najafabad plain at an average annual subsidence rate of $6.7 \mathrm{~cm}$ and a total of $41 \mathrm{~cm}$ during 6 years period and processing of the PALSAR data suggests an annual rate of $7.7 \mathrm{~cm}$ and total subsidence of $30 \mathrm{~cm}$ during 4 years period. Most of the occured displacements are related to the Tiranchi, Koushk, Ghahderijan, Goldasht and Falavarjan cities. The simultaneous groundwater level data with acquisition date of the radar satellite images between 2002 and 2014 shows a drawdown ranging from 0.5 to 46.5 meters in the south and east to north of the Najafabad city consistent with the estimated land subsidence areas. The DInSAR processing of the PALSAR data has led to a more accurate results with higher spatial resolution. Results of the radar data processing can be employed for the hazard zonation directly utilized for management and planning of control and preventive measures.
\end{abstract}

Keywords: The Najafabad aquifer, Land subsidence, Radar interferometry, Differential leveling, ASAR, PALSAR

1. Soil Conservation and Watershed Management Research Department, Isfahan Agricultural and Natural Resources, Research and Education Center, AREEO, Isfahan, Iran.

2. Department of Geology, University of Isfahan, Isfahan, Iran.

3. Water Planning Deputy, Isfahan Regional Water Company, Isfahan, Iran.

Corresponding author, Email: k.shirani@areeo.ac.ir 